Review

\title{
Coordinated Role of Nitric Oxide, Ethylene, Nitrogen, and Sulfur in Plant Salt Stress Tolerance
}

\author{
Badar Jahan $^{1}$, Faisal Rasheed ${ }^{1}$, Zebus Sehar ${ }^{1} \mathbb{D}^{\mathbb{D}}$, Mehar Fatma $^{1}\left(\mathbb{D}\right.$, Noushina Iqbal $^{2}\left(\mathbb{D}\right.$, Asim Masood $^{1} \mathbb{D}$, \\ Naser A. Anjum ${ }^{1}$ (D) and Nafees A. Khan ${ }^{1, *(D)}$ \\ 1 Plant Physiology and Biochemistry Laboratory, Department of Botany, Aligarh Muslim University, \\ Aligarh 202002, India; naziabadar.2014@gmail.com (B.J.); faisalinnovative@gmail.com (F.R.); \\ seharzebus5779@gmail.com (Z.S.); meharfatma30@gmail.com (M.F.); asim.bot@gmail.com (A.M.); \\ dnaanjum@gmail.com (N.A.A.) \\ 2 Department of Botany, Jamia Hamdard, New Delhi 110062, India; naushina.iqbal@gmail.com \\ * Correspondence: naf9.amu@gmail.com
}

\section{check for}

updates

Citation: Jahan, B.; Rasheed, F.; Sehar, Z.; Fatma, M.; Iqbal, N.;

Masood, A.; Anjum, N.A.; Khan, N.A. Coordinated Role of Nitric Oxide, Ethylene, Nitrogen, and Sulfur in Plant Salt Stress Tolerance. Stresses 2021, 1, 181-199. https://doi.org/ $10.3390 /$ stresses 1030014

Academic Editors: Mirza

Hasanuzzaman, Luigi Sanita' di Toppi and Tika Adhikari

Received: 21 August 2021

Accepted: 7 September 2021

Published: 8 September 2021

Publisher's Note: MDPI stays neutral with regard to jurisdictional claims in published maps and institutional affiliations.

Copyright: (c) 2021 by the authors. Licensee MDPI, Basel, Switzerland. This article is an open access article distributed under the terms and conditions of the Creative Commons Attribution (CC BY) license (https:// creativecommons.org/licenses/by/ $4.0 /)$.

\begin{abstract}
Salt stress significantly contributes to major losses in agricultural productivity worldwide. The sustainable approach for salinity-accrued toxicity has been explored. The use of plant growth regulators/phytohormones, mineral nutrients and other signaling molecules is one of the major approaches for reversing salt-induced toxicity in plants. Application of the signaling molecules such as nitric oxide (NO) and ethylene (ETH) and major mineral nutrient such as nitrogen (N) and sulfur (S) play significant roles in combatting the major consequences of salt stress impacts in plants. However, the literature available on gaseous signaling molecules (NO/ETH) or/and mineral nutrients (N/S) stands alone, and major insights into the role of NO or/and ETH along with $\mathrm{N}$ and $S$ in plant-tolerance to salt remained unclear. Thus, this review aimed to (a) briefly overview salt stress and highlight salt-induced toxicity, (b) appraise the literature reporting potential mechanisms underlying the role of gaseous signaling molecules and mineral nutrient in salt stress tolerance, and (c) discuss $\mathrm{NO}$ and ETH along with $\mathrm{N}$ and $\mathrm{S}$ in relation to salt stress tolerance. In addition, significant issues that have still to be investigated in this context have been mentioned.
\end{abstract}

Keywords: ethylene; nitrogen; nitric oxide; salt stress; sulfur

\section{Introduction}

As one of the most disturbing environmental stresses worldwide, salt stress has been projected to significantly increase due to the climate change [1-3]. Excessive salt concentrations were reported in about $7 \%$ of the global land, whereas salt has affected almost $20 \%$ of the arable land and $33 \%$ of the irrigated land in the world [4]. Additionally, by the year 2050, a continued exposure of arid and semi-arid regions to salt stress is predicted to cause about 30-50\% losses worldwide [5]; the salt-affected area is estimated to increase to 16.2 million ha [6]. The increasing land area by salt stress urges plant scientists to build up strategies for sustainable crop production.

The excessive salinity in the rhizospheric zones can negatively affect growth and productivity through creating an imbalance in the cytoplasmic ion homeostasis and thereby impacting metabolic dysfunction and other major biochemical and physiological processes [3,7]. Varied reactive oxygen species (ROS) generated at higher level can occur due to salinity stress in plant cells, can act as signaling molecules, and help in mediating numerous key physiological processes [8]. However, overproduced or non-metabolized ROS can be toxic to plants and cause oxidative damage to cellular constituents including macromolecules (DNA, lipid, and proteins), and, eventually, cause cell death $[9,10]$.

Major mineral nutrients not only constitute a significant part of the agricultural system but also are widely known to modulate the synthesis and production of many plant 
hormones and thereby help in plant-adaptation to stresses including salt stress [2,11]. Nitrogen $(\mathrm{N})$ and sulfur $(\mathrm{S})$, crucial mineral nutrients (macronutrients), are known to exhibit regulatory interactions and regulate plant growth and development [12]. Notably, the synthesis of most amino acids and proteins, nucleic acids, and several other cellular components involves $\mathrm{N}$ [13]. In many instances, $\mathrm{N}$-assimilation and cellular ion homeostasis were reported to contribute in plant tolerance to salt stress $[14,15]$. On the other hand, owing to its occurrence in various S-containing compounds, it serves as a key nutrient known to improve inherent capacity of plant for stress tolerance $[15,16]$. Interestingly, most plant nutrients are interrelated with several phytohormones, where their synergistic or antagonistic actions contribute in modulation of the physiological/biochemical responses leading to salt tolerance [2].

Nitric oxide (NO) is a gaseous phytohormone and a reactive nitrogen species (RNS). As a free radical gaseous signaling molecule, $\mathrm{NO}$ is involved in plant development and nutrient assimilatory processes and also improves plant tolerance to major stresses such as the soil salinity [17-20]. Ethylene (ETH) is another gaseous phytohormone that influences plant responses to salt stress [21,22]. Various studies have shown the interaction of NO and ETH with $\mathrm{N}$ and $\mathrm{S}$ under abiotic stress. Studies have reported the interactive effects of NO with $\mathrm{N}$ and S [2] and ETH with N and S [10]. N-availability was reported to influence ETH -production and improve salt tolerance in mustard [23], whereas NO was found to enhance the photosynthetic nitrogen use efficiency (PNUE) and photosynthetic sulfur use efficiency (PSUE). Owing to the occurrence of a close link between the assimilation of $\mathrm{N}$ or $\mathrm{S}$ with salt stress tolerance, the identification and analyses are imperative to enlighten how much $\mathrm{N}$ or $\mathrm{S}$ assimilation is induced by phytohormones or vice-versa in order to counteract the salt stress-consequences in plants. The understanding of the role of NO and ETH in the regulation of assimilation of $\mathrm{N}$ or $\mathrm{S}$ may help in highlighting insights into the plant salt tolerance induced by $\mathrm{N}$ - or S-assimilation.

Considering the above aspects, this paper: (i) overviews major salt stress-impacts in plants; (ii) appraises literature available on the role and coordination-outcomes of $\mathrm{N}$ and S in plant salt tolerance; (iii) presents discussion on the role of $\mathrm{NO}$ and $\mathrm{ETH}$, and the significance of crosstalk of ETH and NO with N and S in plant salt tolerance; and (iv) enlightens so far unexplored aspects in the current context.

\section{Salt Stress: An Overview}

Contingent to the amounts and type of salts, also the amount of sodium present and soil alkalinity, salt-affected soils can be non-saline or sodic and saline (Table 1).

Table 1. Different categories of soil salinity.

\begin{tabular}{ccccc}
\hline Soil Types & ECe $(\mathbf{d S} / \mathbf{m})$ & ESP & SAR & pH \\
\hline Non-saline soil & $<4$ & $<15$ & $<15$ & $4.5-75$ \\
Saline soil & $>4$ & $<15$ & $<15$ & $<8.5$ \\
Sodic soil & $<4$ & $>15$ & $>15$ & $>8.5$ \\
Saline-sodic soil & $>4$ & $>15$ & $>15$ & $>8.5$ \\
\hline
\end{tabular}

ECe, electrical conductivity; ESP, exchangeable sodium percentage (relative amount of the Na ion present on the soil surface; SAR, sodium adsorption ratio (a measure of the amount of Na relative to $\mathrm{Ca}$ and $\mathrm{Mg}$.

Salt stress is the issue of almost all the continents and under a wide range of climates. Conversely, this stress issue is more urgent in arid and semi-arid climates contrasted with the humid climate, where yearly precipitation is not as much as evapotranspiration in the world. At a global scale, about 12,781 Mha areas are affected by salinity and sodicity stresses. The regions with a preponderance of salt-affected soils are shown in Table 2. 
Table 2. Regional distribution of salt-affected soils (Mha).

\begin{tabular}{cccccc}
\hline Regions & Total Area & Sodic Soils & Percentage & Saline Soils & Percentage \\
\hline Africa & 1899.1 & 33.5 & 1.8 & 38.7 & 2.0 \\
Asia-Pacific and Australia & 3107.2 & 248.6 & 8.0 & 195.1 & 6.3 \\
Europe & 2010.8 & 72.7 & 3.6 & 6.7 & 0.3 \\
Latin America & 2038.6 & 50.9 & 2.5 & 60.5 & 3.0 \\
Near East & 1801.9 & 14.1 & 0.8 & 91.5 & 5.1 \\
North America & 1923.7 & 14.5 & 0.8 & 4.6 & 0.2 \\
World's Total & $12,781.3$ & 434.3 & $3.4 \%$ & 397.1 & $3.1 \%$ \\
\hline
\end{tabular}

It is remarkable to note that $\sim 85 \%$ of the total global area is only slightly to moderately affected by high salt concentrations; whereas, from harsh to extreme limitations for crop production occur in the remainder 15\% [24]. The countries where significant salt-affected soils exist including but not limited to such as India (27\%); Pakistan (28\%), Israel (13\%), Australia (20\%), China (15\%), Iraq (50\%), and Egypt (30\%) [25].

\subsection{Salinity Stress Impacts in Plants}

\subsubsection{Growth and Development}

Salinity-impact on the germination has been reported in several crop plants including Brassica juncea [10], Oryza sativa [26], and Triticum aestivum [27]. In salinity (EC $12 \mathrm{dS} \mathrm{m}^{-1}$ )exposed $B$. juncea genotypes, a significant correlation existed between tolerance index and shoot length, dry matter and also salt tolerance efficiency [28]. In addition to significant reductions of shoot and root length, the highest $\mathrm{NaCl}(200 \mathrm{mM})$ caused the highest decrease in the germination percentage, germination index and speed of germination in Helianthus annuus [29]. Salinity (50, 100, and $150 \mathrm{mM} \mathrm{NaCl)-exposed} \mathrm{Pistacia} \mathrm{vera} \mathrm{exhibited} \mathrm{a} \mathrm{negative}$ relationship between salinity stress and vegetative growth parameters [30]. A differential impact of salinity on the fresh and dry weights of the shoot system can be controlled by many factors including changes in salinity concentration, type of salt present, or type of plant species [31]. Compared to roots, salinity regimes impact shoots to a greater extent [32]. In another study, $100 \mathrm{mM} \mathrm{NaCl-exposed} \mathrm{Medicago} \mathrm{sativa} \mathrm{seedlings} \mathrm{showed} \mathrm{a} \mathrm{marked} \mathrm{reduction}$ in dry weight of root and shoot (along with reduced nodulation) [33]. The genotypes of $B$. juncea exhibited greater reductions in shoot and root biomass and leaf area under $50 \mathrm{mM}$ $\mathrm{NaCl}$-exposure [34].

\subsubsection{Photosynthetic Functions}

Abiotic stresses including salinity have been widely shown to severely impact all the phases of photosynthesis, the most fundamental and intricate physiological process in plants $[2,22,35]$. In fact, the overall status of photosynthesis can be due to stress-induced change in its various components including photosynthetic pigments and photosystems, the electron transport system, and $\mathrm{CO}_{2}$ reduction pathways.

Chlorophyll (Chl) is among the sensitive indicators of cellular metabolic state [35]. The content of $\mathrm{Chl} a$ and $\mathrm{Chl} b$ was significantly reduced under salinity in cucumber seedlings [16]. The photosynthetic pigments as $\mathrm{Chl}$ a and $\mathrm{Chl} \mathrm{b}$, carotenoids and net photosynthesis rate along with stomatal conductance were highly affected by the salt concentration in water melon plants [36]. In another study, $100 \mathrm{mM} \mathrm{NaCl}$-mediated reduction of $\mathrm{Chl} \mathrm{a,} \mathrm{Chl} \mathrm{b}$ and carotenoids contents was shown in rice [37]. In salinityexposed T. aestivum, a greater decline in the photosynthetic rate and electron transport rate and saturating photosynthetically active photo flux density was noted [22]. Moreover, there were reductions in the number of photosynthetic pigments such as $\mathrm{Chl}$ and carotenoids with the net photosynthesis, stomatal conductance, intercellular $\mathrm{CO}_{2}$ concentration, and transpiration rate under stress in tomato plants [38].

The photosystem II (PS II) is the prime site affected by any change in electron transport chain activity due to stress such as salinity [39]. Severe reduction in the efficiency of PS II, the electron transport system, and the $\mathrm{CO}_{2}$ assimilation rate under salinity stress has been reported [22]. Decreased growth was obtained in barley plants due to salt-accrued 
damaged Chl fluorescence and oxygen evolving complex [40]. It has been observed that growth becomes reduced in plants due to damage of PS II and electron transport rates under stress [41]. In B. juncea, the increased concentration of salt significantly impacted net photosynthetic rate, stomatal conductance, intercellular $\mathrm{CO}_{2}$, quantum yield of PS II, Rubisco activity, and PNUE [10]. The study of Singh et al. [42] showed the response towards variable concentration of salt, which hampered the photosynthetic apparatus and the water splitting efficiency complex. The photosynthetic pigment content and plant growth were greatly reduced under salinity stress in salt-sensitive Sorghum plants [43]. Salt stress was also reported to cause reductions in leaf area, pigment content, Hill reaction, ${ }^{14} \mathrm{CO}_{2}$ fixation, morphology of chloroplasts, number of reaction centers, net $\mathrm{CO}_{2}$ assimilation rate, and Rubisco activity in wheat [44]. Salinity-mediated down regulation of photosynthetic gas exchange rate, water utilization efficiency was reported to lead to reductions in quantum yield of PS II, photochemistry, and photochemical quenching [45]. Hussain et al. [46] showed that salt stress reduced net photosynthetic rate, and intercellular $\mathrm{CO}_{2}$ concentration in rice.

\subsubsection{Oxidative Stress and Antioxidant Metabolism}

Salt stress can enhance the peroxidation of macromolecules through oxidative damage of membrane components [47]. However, peroxidation of lipids can be caused even at mild levels of abiotic stress [48]. In $\mathrm{NaCl}(0.5,0.1$ and $4 \mathrm{M})$-exposed Dunaliella salina and Dunaliella tertiolecta, increased $\mathrm{H}_{2} \mathrm{O}_{2}$ content was positively correlated with the level of thiobarbituric acid reactive substances (TBARS) [49]. In B. juncea, an increase in TBARS content with increasing the degree of soil salinity was noted by Fatma et al. [16] and Jahan et al. [10].

The major components of antioxidant defense system can be differentially modulated by salinity stress $[2,22]$. Salinity stress was observed to induce oxidative damage by increasing electrolyte leakage and the contents of $\mathrm{H}_{2} \mathrm{O}_{2}$, malondialdehyde (MDA), and the activity of superoxide dismutase (SOD), peroxidase (POX), and catalase (CAT) [50]. Salinity-accrued enhancements in the activity of ascorbate peroxidase (APX), CAT, some peroxiredoxins, glutathione/thioredoxin peroxidases, and glutathione S-transferase (GSTs) during salinity stress were argued to be involved in the metabolism of $\mathrm{H}_{2} \mathrm{O}_{2}$ [51]. In Glycine max., $\mathrm{NaCl}$ stress elevated the activity of CAT and APX to minimize the toxic effects of salinity [52]. Salinity-induced increases in the cellular $\mathrm{H}_{2} \mathrm{O}_{2}$ and concomitant enhancements in the activity of CAT and APX were found in plants [16]. Increased GSH content and elevation in the activity of SOD, $\mathrm{H}_{2} \mathrm{O}_{2}$-metabolizing (APX), and GSH-regenerating (GR) enzymes were found to be significantly higher in leaves of salt-exposed wheat [22].

\subsubsection{Nutrients Uptake, Assimilation and Related Traits}

Elevation in the soil salinity impacts the uptake and metabolism of the major plant nutrients including calcium $(\mathrm{Ca})$, potassium $(\mathrm{K})$, phosphorous $(\mathrm{P}), \mathrm{N}$ and $\mathrm{S}[10,53]$. Changes in $\mathrm{K}^{+}$-selective ion channels activity or the changes in osmotic potential of solution are bound to reduce the mass flow of most of these mineral nutrients in roots under salt stress [54]. In fact, insufficient supply of one nutrient may affect the amount of the other element which in turn, may hamper the growth of plants by altering their metabolic pathways. Hence, due to the accomplished various roles of these nutrients in plants, they tend to take up (and assimilate) these elements in order to cope particularly with the stressed condition [10]. However, salinity may inhibit or promote nutrient uptake and metabolism by different plant species contingent to types of plants and their organs, salinity levels and nutrients. Salinity stress is known to impact $\mathrm{N}$ assimilation by impairing $\mathrm{N}$-uptake, $\mathrm{NO}_{3}{ }^{-}$reduction, and $\mathrm{NH}_{4}{ }^{+}$assimilation [55]. In addition, the supply of $\mathrm{S}$ to salt-treated plants improved plant salt tolerance [56]. Salinity is known to inhibit $\mathrm{K}^{+}$ uptake which decreases the $\mathrm{K}^{+} / \mathrm{Na}^{+}$ratio and control overall plant salt-tolerance [57]. In fact, salt stress provokes the rapid depolarization of the plasma membrane potential that in turn activates voltage gated GORK (guard cell outward rectifying $\mathrm{K}^{+}$) channels and 
results in $\mathrm{K}^{+}$efflux [58]. Adverse effects of salinity on PSII activity and eventual hampered growth and productivity may also involve salinity-caused reduced uptake and deficiency of Mn [59]. The solubility and P uptake in plants can also be impacted by changes in soil- $\mathrm{Na}^{+}$concentration and $\mathrm{pH}[60,61]$.

\subsubsection{Crop Yield}

The final yield of most crops displayed brutal yield losses even under moderate salt stress may involve changes in the soluble salts in the rhizosphere [62]. Negative association of different yield components with soil-salinity levels has been widely reported [63,64]. Thus, as the main research priority, devising explicit means is imperative in order to recover crop productivity on salt-affected soils (Figure 1). To this end, crop breeding comprising both predictable breeding and modern molecular marker-assisted breeding could be of great help [65].
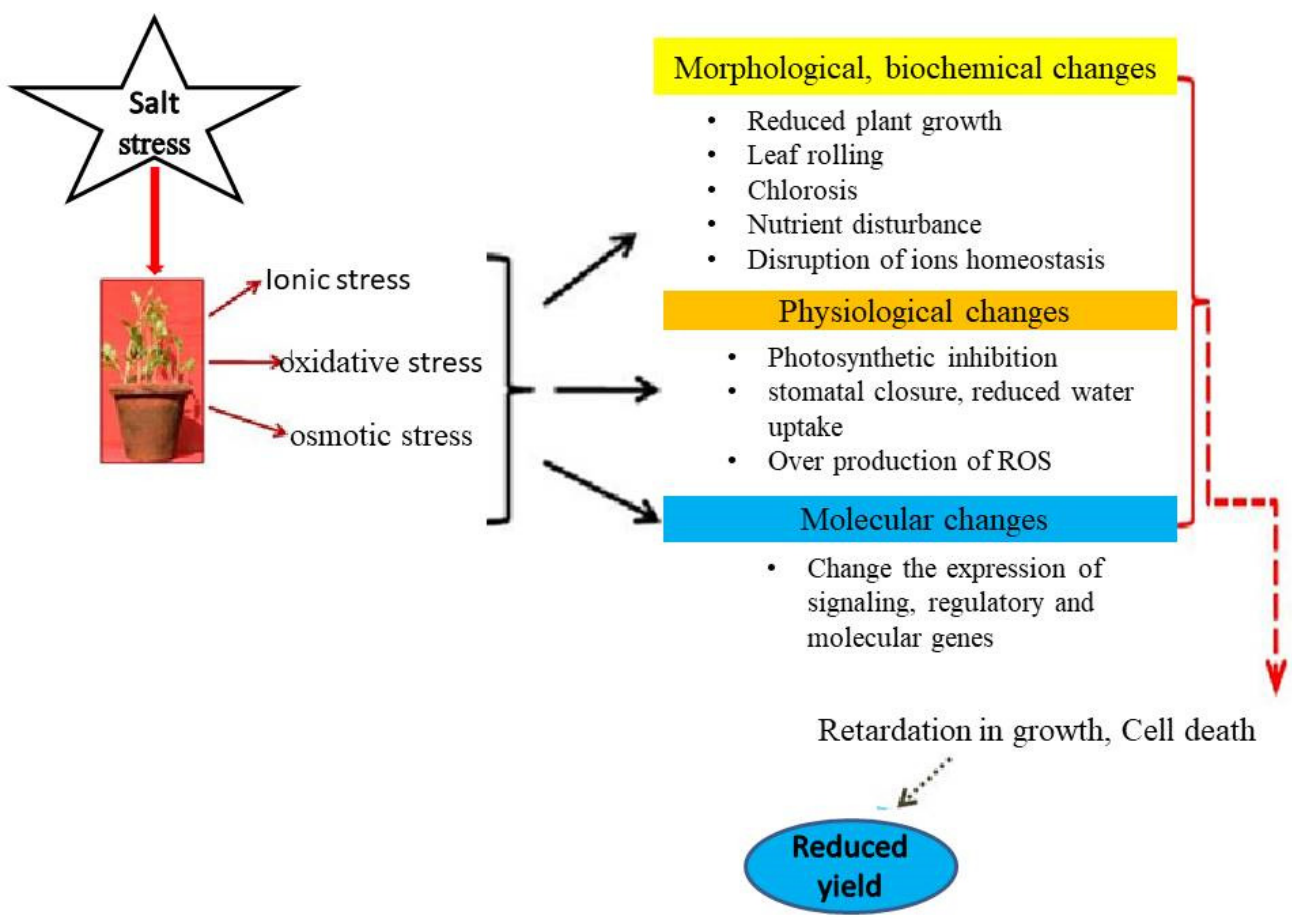

Figure 1. Schematic representation of the major influence of salt stress on plant metabolism and functions.

\section{Nitrogen in Salt Tolerance}

The uptake of $\mathrm{N}$ and its assimilation in plants have been widely found to be impacted by salinity stress $[2,66]$. Salinity $(50 \mathrm{mM} \mathrm{NaCl})$-mediated decreases in the contents of both $\mathrm{N}$ and $\mathrm{S}$ were reported in B. juncea [67]. In Hordeum vulgare, $\mathrm{S}$ assimilation was highly impacted with $100 \mathrm{mM} \mathrm{NaCl}$ that in turn reduced the cellular thiols (-SH) in plants [68]. The concentration of $\mathrm{NaCl}(100 \mathrm{mM})$-mediated decrease in $\mathrm{N}$ uptake was found in T. aestivum [66]. There was a drastic reduction of $\mathrm{N}$ content in the form of nitrate $\mathrm{NO}_{3}{ }^{-}$in the cultivars of $\mathrm{O}$. sativa when exposed to $150 \mathrm{mM} \mathrm{NaCl}$ [69]. In addition to impacting the content of the major non-enzymatic antioxidants, salt stress inhibited the activity of antioxidant enzymes and enzymes involved in $\mathrm{N}$-assimilation [3,70]. Major genes involved in the uptake and transport of $\mathrm{N}$, and assimilation can also be affected by high salinity [71]. To this end, five genes (BjAMT1.2, BjAMT2, BjGS1.1, BjGDH1, and BjASN2) were down-regulated, whereas three genes (BjNRT1.1, BjNRT1.5, and BjGDH2) were up-regulated under salt stress [71]. It was concluded that the reduction in NR in plants may lead to down-regulation of gene participating in $\mathrm{N}$ assimilation under salinity stress. $\mathrm{N}$-supplementation restricted $\mathrm{Na}^{+}$-accumulation and improved plant-K status, and 
thereby increased growth [72]. Furthermore, N-supply also regulated ROS-homeostasis and alleviated salt-toxicity [73]. $\mathrm{NH}_{4}{ }^{+}$supplementation induced salt-tolerance through efficient $\mathrm{N}$-uptake and assimilation processes and controlled $\mathrm{K}^{+} / \mathrm{Na}^{+}$homeostasis [74]. The N-supplementation with brassinosteroids seed priming also improved plant salttolerance [75].

\section{Sulfur in Salt Tolerance}

The maintenance of the S-status and the major biochemical and molecular studies to this end have reported to improve plant abiotic stress tolerance [76,77]. In fact, S-containing compounds (including cysteine, Cys; glutathione, GSH) significantly help in cellular redox homeostasis and thereby minimize plant protection against oxidative stress [78-83]. GSH acts as an important water-soluble and low molecular weight antioxidant; a major component of AsA-GSH cycle; and the main non-protein source of $S$ to the plants $[79,81]$. Furthermore, GSH interacts with diverse stress and defense-related signaling molecules and can modulate their pathways, thereby combatting stress-impacts [80]. Adequate S-supply can enhance the content of GSH and improve photosynthetic and growth characteristics in salt stressed plants $[16,78]$. The imposition of salt stress significantly increased S-assimilation and the biosynthesis of Cys and GSH [2]. In addition, S-supplementation was also observed to improve ascorbic acid (AsA), total phenolics, tocopherol, lycopene, and antioxidant capacity, and decreased $\mathrm{H}_{2} \mathrm{O}_{2}$ and MDA content in $\mathrm{Z}$. mays under salt conditions [84]. S-supply can also attenuate the inhibitory effects of salt stress on gas exchange attributes and growth of lettuce plants, decrease $\mathrm{Na}^{+} / \mathrm{K}^{+}$ratio, and improve uptake of K and P [85]. Moreover, supplementation of S reduced the electrolyte leakage and $\mathrm{Na}^{+}$accumulation while increasing $\mathrm{K}^{+}$and $\mathrm{Ca}^{2+}$ and photosynthetic rate under high salt-stressed sunflower plants [86].

\section{Coordination of $\mathbf{N}$ and $\mathbf{S}$ in Salt Stress Tolerance}

The major outcomes of the coordinated actions between $\mathrm{N}$ and $\mathrm{S}$ have emerged as an important strategy for improving plant growth and productivity under environmental stresses $[10,67]$. In fact, there occurs functional convergence and good coordination between $\mathrm{N}$ and $\mathrm{S}$ uptake, reduction assimilatory pathways $[2,87,88]$. The status of nitrate reductase (NR; involved in N-assimilation) and ATP-sulfurylase (ATP-S; involved in Sassimilation) showed mutual interaction in terms of their coordinated role in Cys-synthesis and GSH-production [2]. Particularly, there exists a close relation among GSH and S and $\mathrm{N}$ [2]. The availability of its constituent amino acids, Cys, glutamine and glycine are connected with the biosynthesis of GSH which contains three moles of $\mathrm{N}$ per mole of S. Notably, the glutamine synthetase (GS)-glutamate synthase (GOGAT) pathway of N assimilation yields glutamic acid; whereas, S-assimilation ends with Cys synthesis [2]. In this way, the coordinative functions of $\mathrm{S}$ and $\mathrm{N}$ may strengthen plant capacity for stresstolerance. The literature is full on the recognition of regulatory interactions between $\mathrm{N}$ and $S$ assimilation, and its significance in plant stress tolerance $[2,67,89]$. The synergistic relationship of $\mathrm{N}$ and $\mathrm{S}$ also contributed in enhancing plant growth, photosynthetic efficiency and proline accumulation under salt stress [90]. The basal supplementation of $S$ with foliarly applied salicylic acid (SA) to salt treated plants modulated enzymes involved in $\mathrm{N}$ assimilation, and GOGAT cycle [15]. During $\mathrm{N}$-deficiency, hydrogen sulfide $\left(\mathrm{H}_{2} \mathrm{~S}\right)$ and rhizobia synergistically regulated assimilation and remobilization of $\mathrm{N}$ and also modulated senescence-associated genes expression [91]. However, the literature is scanty on N-S interactive effects in minimization of salt toxicity. The synergistic relationship of $\mathrm{N}$ and $\mathrm{S}$ also contributed to enhancement of growth and crop productivity [89]. The relationship of $\mathrm{N}$ and $\mathrm{S}$ in terms of crop yield and quality has also been recognized in several studies [89]. It is imperative to unveil more insights into N-S coordination, and their cumulative role in plant salt-tolerance at physiological/biochemical and molecular levels. 


\section{Nitric Oxide}

Nitric oxide (NO), the smallest diatomic gas (30.006 $\left.\mathrm{g} \mathrm{mol}^{-1}\right)$, has emerged as a gaseous signaling molecule in plants and has also been reported to exhibit its connection with a range of phenomena from germination and senescence to photosynthesis and cellular redox balance $[1,17,81,92-94]$. NO can easily diffuse across the plant cells and contribute to signal transduction pathways by interacting with different cellular compounds and radicals [95]. Even low ( $\mu \mathrm{M}$ and $\mathrm{nM}$ ) levels of NO can confer plant tolerance to a range of stresses including metal toxicity, salt, drought, high temperatures by mainly modulating the major components of antioxidant defense system and thereby limiting elevated ROS-accrued oxidative stress $[1,2,10,17,19,96,97]$. Both exogenous supplementation of NO-donors [e.g., sodium nitroprusside (SNP)], NO-scavengers [e.g., 2-(4-carboxyphenyl)-4,4,5,5-tetramethylimidazoline-1-oxyl-3-oxide (cPTIO)] and enzyme inhibitors were widely used to elucidate NO-roles in stressed plants. NO can activate secondary messengers and/or induce transcription of genes and thereby control diverse processes in plants [98]. Moreover, NO can also directly modify proteins, and react with residues of Cys (S-nitrosylation), tyrosine (nitration), or iron and zinc in metalloproteins (metal nitrosylation) [99].

\subsection{NO Generation and Signaling}

Cytoplasm, chloroplasts, mitochondria and peroxisomes are the major sites of NOgeneration in plants [100]. Notably, major pathways for NO generation discovered to date in plants can be categorized into namely enzymatic and non-enzymatic pathways [20]. In enzymatic pathways, cytosolic nitrate reductase (NR; EC 1.6.6.1) and NO synthase (NOS; EC 1.14.13.39) catalyze NO-generation. However, nitrite NO-reductase (Ni:NOR) and xanthine oxido-reductase (XOR) [100,101], and the heme proteins [102] have also been argued to be involved in the enzymatic generation of NO [102]. Moreover, enzyme NO synthase NOS (EC 1.14.13.39) is involved in the production of endogenous NO in mammals [103]. In A. thaliana genome, AtNOA1 (NITRIC OXIDE ASSOCIATED 1) is indirectly involved in $\mathrm{NO}$ production [94].

In plants, enzymatic endogenous NO-generation has been assumed to mainly involve NR $[104,105]$. Restricted to the cytosol NR has been suggested to catalyze the reduction of $\mathrm{NO}_{3}{ }^{-}$to $\mathrm{NO}_{2}{ }^{-}$using NADPH as the main electron donor [103]. Nevertheless, revealed through in vitro and in vivo experiments, low oxygen concentration and cellular $\mathrm{pH}$ were argued as two of the most important requirements for the activity of NR [104]. In Arabidopsis, the NR enzyme encoded redundantly by NIA1 and NIA2 genes is capable of reducing nitrite to NO [106]. In addition to highlighted enzymatic sources of NO-generation in plants, NO can be generated non-enzymatically as a by-product of denitrification, fixation of $\mathrm{N}$ and respiration. At $\mathrm{pH}$ range between 3.0-6.0, AsA-mediated reduction of nitrite yields NO and dehydroascorbic acid [105].

Owing to its lipophilic and highly diffusible in nature, NO is involved in several signaling processes in plants [107]. The list of NO-derivatives, usually referred to as RNS includes $\mathrm{NO}$ radicals $\left(\mathrm{NO}^{-}\right)$, nitrosonium cation $\left(\mathrm{NO}^{+}\right)$, peroxynitrite $\left(\mathrm{ONOO}^{-}\right)$, S-nitrosothiols (SNOs), higher oxides of $\mathrm{N}(\mathrm{NOx})$ and dinitrosyl-iron complexes [108]. S-nitrosoglutathione (GSNO) is yielded as a result of the reaction of $\mathrm{NO}$ with reduced GSH in presence of $\mathrm{O}_{2}$. In turn, NADH-dependent S-nitrosoglutathione reductase (GSNOR) decomposes GSNO to GSSG and $\mathrm{NH}_{3}$ [109]. NO synthesized during these processes can induce diverse effects in plants [110]. Conflicting reports are accessible about NO induced changes, where some studies show $\mathrm{NO}$ as a stress inducing agent [111], even as others have mentioned it as a protective agent [17]. In order to play signaling function, NO has been shown to interact with second messenger, such as, cyclic guanosine monophosphate (cGMP), cytosolic $\mathrm{Ca}^{2+}$ ion concentration, and cADP-ribose, phosphatidic acid and ROS [112]. NO-mediated regulation of the activity of enzymes may involve post-translational modifications and joining themselves with metal centers of proteins. NO may also alter the aggregation state, activity, or location of residue of Cys and tyrosine of proteins [99]. NO-mediated nitration 
of fatty acids is an imperative part of NO signaling in plants [113]. NO can also initiate mitogen-activated protein kinase (MAPK) signaling pathways in plant cells [114]. MAPK cascade (MEK2-SIPK) induces NO ASSOCIATED1 and NR-mediated NO burst [115]. In particular, SIPK can give positive feedback between NO and ROS signals and MAPK cascades can act to regulate ROS and NO production in plants [115]. Reduction in ROS levels, mitigation of oxidative stress and the role as an anti-senescence agent can be performed by the mitochondrial NOS (NOS1).

\subsection{Nitric Oxide in Salt Tolerance}

The literature supports the involvement of NO in plant stress-response mechanisms, which are largely contradictory, and are contingent to plant species types and the extent of the salt treatment. On the one hand, NO-mediated improvement in plant health was reported to involve improved osmolytes accumulation and strengthened antioxidative defense systems [116]. $\mathrm{NO}$ can also mitigate $\mathrm{H}^{+}$-ATPase inhibition, enhance mineral absorption and maintain hormone equilibrium; and thereby attenuate growth inhibition [117]. The NO-melatonin interaction regulates the expression of $\mathrm{Cu} / \mathrm{Zn}-\mathrm{SOD}$ and Mn-SOD, eventually maintains oxidative homeostasis in plants under salt stress [118]. Moreover, the family of protein kinase is also involved in NO-mediated signaling cascades in salt stressed plants. Furthermore, comparative study of NO and SA was done to study their impact on salt-stress mitigation. The results speculated that $\mathrm{NO}$ enhanced salt tolerance due to antioxidant enzymes and compatible solute. However, SA was effective to reduce MDA and $\mathrm{H}_{2} \mathrm{O}_{2}$ content [119]. The supplementation of NO and jasmonic acid (JA) was reported to mitigate salt stress toxicity through modulation of antioxidant enzymes [96]. NO-interaction with phytohormones can be useful in plant salinity tolerance. In Arabidopsis, abiotic stress can reduce root meristem growth by decreasing accumulation of auxin-mediated by NO [120]. The auxin-mediated initiation of NADPH-dependent thioredoxin reductase (NTR) activity is reduced by NO scavengers, signifies that $\mathrm{NO}$ is downstream of auxin in this regulatory pathway. NO was observed to efficiently reduce the inhibitory effects of salt stress on growth rates and exosmosis of electrolytes and decreases the lipid peroxidation in wheat as a result of increment in cytokinin (CK) [121]. Furthermore, the supply of absicsic acid (ABA) improves the production and participation of $\mathrm{NO}$ downstream of ABA and thereby controls processes including seed germination, dormancy and stomatal movement [122].

\section{Ethylene}

First identified as a simple gaseous molecule $\left(28.054 \mathrm{~g} \mathrm{~mol}^{-1}\right)$ ethylene (ETH; $\left.\mathrm{CH}_{2}=\mathrm{CH}_{2}\right)$, is produced in all higher plants and usually connected with fruit ripening and the triple response. ETH has been reported first as the active component in illuminating gas caused a triple response in etiolated pea seedlings [123]. The development of $A$. thaliana as a model system and eventual development and screening of genetic mutants largely contributed in ETH signaling [124]. The extension in our understanding on how this phytohormone works was possible as a result of the identification of gene array and transcriptional factors working downstream [125].

Ethylene regulates diverse aspects of plant growth responses and development [126] and also plays very important roles in photosynthesis under abiotic stress [22] by regulation of stomatal movement and more influx of $\mathrm{CO}_{2}$ important for carboxylation [127]. The list of major factors involved in the potential control of ETH-production includes internal signals throughout the development and plant responses under varied abiotic (nutritional disorders, wounding, hypoxia, ozone, chilling, or freezing) and biotic (e.g., pathogen attack) stresses [128]. Furthermore, ETH can regulate $\mathrm{H}^{+}$-ATPase gene expression and thereby control ion homeostasis in salt stressed plants [129].

\subsection{Ethylene Biosynthesis and Signaling}

The ETH biosynthetic pathway in higher plants is well described [130-133]. ETHproduction is strictly regulated at various levels and involves both transcriptional [134], 
post-translational regulation [135]. ETH-signaling cascade starts with first perceived by a family of membrane-bound receptors, predominantly localized at the endoplasmic reticulum (ER). In Arabidopsis, ETH-receptors (ETHYLENE RECEPTOR1 and 2 (ETR1/2), ETHYLENE RESPONSE SENSOR 1 and 2 (ERS1/2) and ETHYLENE INSENSITIVE 4 (EIN4) perceive ETH and also involves a number processes [136]. In particular, EIN3 and its close homolog, ETHYLENE INSENSITIVE3-LIKE1 (EIL1) are key transcription factors activated by EIN2 [137].

\subsection{Ethylene in Salt Tolerance}

ETH signaling contributes in plant stress responses and tolerance to abiotic stresses including salinity $[16,22,138]$. ETH can maintain the homeostasis of ions and also upregulate antioxidant enzymes in plants under environmental fluctuation [139]. Exogenous application of ACC lowered osmotic stress and controlled non-photochemical quenching (NPQ) via PSI cyclic electron flow and starch metabolism in tomatoes under salt stress [21]. MAPK cascade-mediated control of the activation of different defense mechanisms also contributes in response to ROS stress [140].

The supply of ETH-releasing compounds (such as ethephon), ETH-precursors (such as ACC) and/or endogenous ETH-overproduction were reported to confer plant salt tolerance [141,142]. ETH may act as both a positive regulator and or a negative regulator in salt stress-resistance in plants. To this end, application of 1-MCP, an ETH-action inhibitor improved physiological and biochemical antioxidant characteristics [46]. Calcium carbide $\left(\mathrm{CaC}_{2}\right)$, a precursor of ETH was reported to exhibit its ability to alleviate salt stress and improve ETH-concentration, seed germination, osmolytes and activities of $\alpha$-amylase and decrease $\mathrm{H}_{2} \mathrm{O}_{2}$ and MDA contents under salt stress [143]. Ethylene contribution to salt acclimation processes can differ with respect to the type of response, including improved expression of ETH receptors and ETH production [144]. However, ETH involvement in plant response to salt resistance is highly complex and still remains unclear. In addition, EIN3/EILs are the key elements and positive factors in ETH-mediated downstream transcriptional cascade [145]. EIN3/EILs are involved in many physiological processes, seed germination, apical hook formation, fruit development, abiotic stress and hormone responses $[145,146]$. A recent report indicates that EIN3/EIL1 are necessary for the enhanced ETH-induced salt tolerance in Arabidopsis and salt stress leads to a large number of EIN3/EIL1-regulated genes via promoting EBF1/EBF2 proteasomal degradation in EIN2dependent and EIN2-independent pathways [147]. Overexpression of EIN3 target genes (e.g., ERFs and SALT INDUCED EIN3/EIL1-DEPENDENT1 (SIED1)) in a range of plant species leads to salt tolerance [144]. Moreover, melatonin was also reported to enhance plant salt-tolerance by promoting MYB108A-mediated ETH biosynthesis [148].

Signaling molecules such as ABA, CK, indole acetic acid (IAA), gibberrelins (GA), ROS, and $\mathrm{Ca}^{2+}$ interacts with ETH and thereby contribute in plant stress-adaptation $[15,138,149,150]$. The DELLA proteins and GA-opposable growth inhibitors of the GA signaling pathway participate in plant salt-tolerance [151]. In particular, ETH-mediated increase in the accumulation of DELLA proteins reduced the action of GA [138]. ABA was reported to regulate the ETH biosynthesis-associated genes (AtACS5, AtACS7, TaACO1, and GhERF1) under salt stress [138]. ETH and JA may act synergistically or antagonistically in response to stressed conditions and mediate via EIN3/EIL1 along with JAZs-MYC2 [152].

The relationship between ETH and SA are antagonistic, conferring tolerance against environmental fluctuation [153]. The application of SA restricted the ETH production by inhibiting the activity of ACC synthase under salt stress [154]. As a result, the reduction in the synthesis of ETH alleviated the toxicity of salt stress. Nazar et al. [155] suggested that SA treatment constrained the ETH formation by inhibiting the ACC synthase activity under drought stress. Interactive outcomes of ETH, $\mathrm{H}_{2} \mathrm{O}_{2}$, and brassinosteroids were reported to confer plant-tolerance against salt stress [156]. 


\section{Crosstalk of NO with N and S in Salt Tolerance}

The NO generation and assimilation of $\mathrm{N}$ are closely connected. Both the amount and also the form of the supplied $\mathrm{N}$ (i.e., $\mathrm{NO}_{3}{ }^{-}$or $/ \mathrm{NH}_{4}{ }^{+}$) affect levels of $\mathrm{NO}$ in plants [157]. Nitrite $\left(\mathrm{NO}_{2}{ }^{-}\right)$and arginine are the main substrates for NO synthesis. Plants were reported to optimize the use of nitrite as a main source for $\mathrm{NO}$ [158]. NO-regimes were reported to exaggerate the activity NR, a key enzyme in N-metabolism, and a NO-source [159]. NO was also argued to modulate the uptake and distribution systems of $\mathrm{N}$ [160]. In addition to its role in $\mathrm{N}$ assimilation and uptake, involvement of $\mathrm{NO}$ in nitrate-sensing pathway was also reported in plants [161]. The reaction of NO with GSH produces GSNO, a lowmolecular-weight S-nitrosothiol (SNO). Notably, more stable than NO, SNO serves as a mobile reservoir of NO. However, GSH content can also regulate plant's S-status through induced S assimilation and forms GSNO [17,162]. The coordination of NO with S can maintain ionic and redox homeostasis, strengthen the plant antioxidant machinery, and thereby improve photosynthetic performance, growth, and salt tolerance [17]. Figure 2 summarizes $\mathrm{N}$ and $\mathrm{S}$ assimilation and how their coordination with $\mathrm{NO}$ helps in salt tolerance in plants.

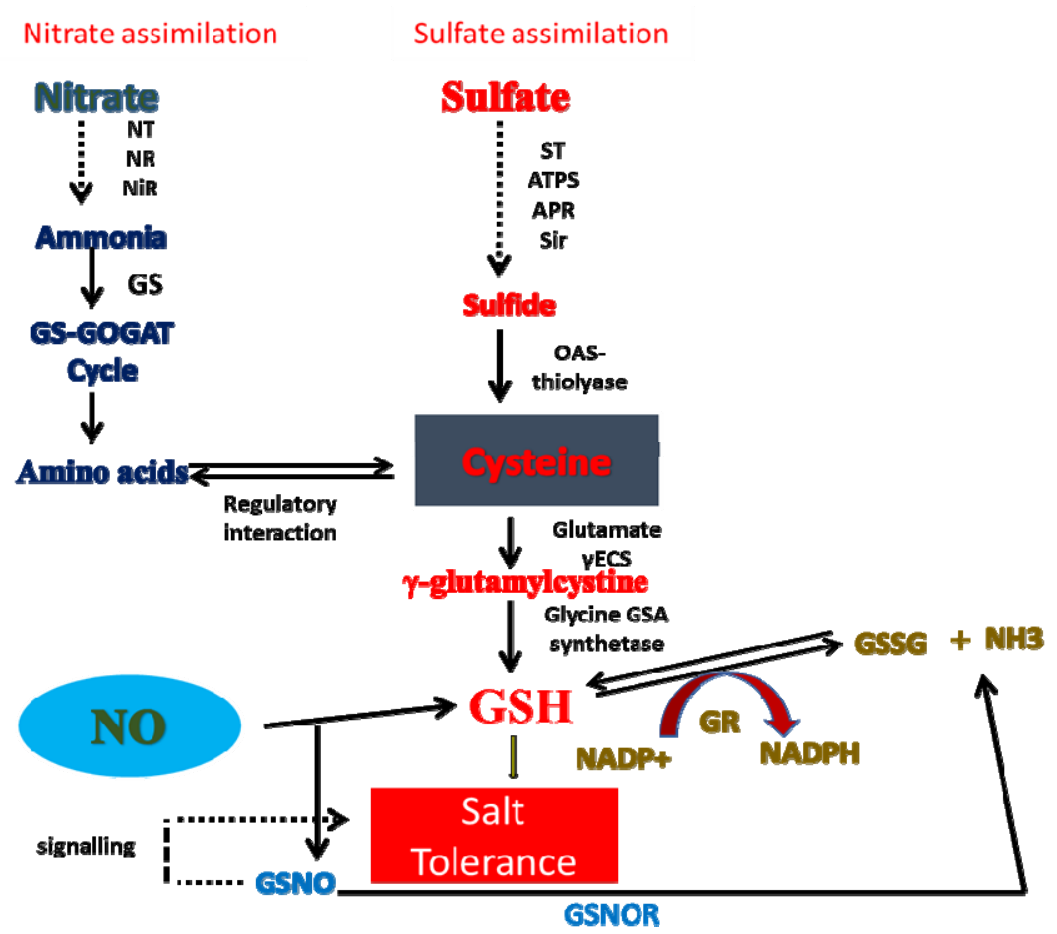

Figure 2. Regulatory interaction between nitrogen $(\mathrm{N})$ and sulfur $(\mathrm{S})$ assimilation and nitric oxide (NO) biosynthesis linked with salinity stress tolerance. APR, adenosine $5^{\prime}$ phosphosulfate reductase; ATP-S, ATP sulfurylase; GR, glutathione reductase; GS, glutamine synthetase; GSH, glutathione reduced; GSNO, S-nitrosoglutathione; GSNOR, GSNO reductase; GSSG, glutathione oxidized; NADPH, nicotinamide adenine dinucleotide phosphate;NR, nitrate reductase; NiR, nitrite reductase; NT, nitrate transporter; OAS-TL, O-acetylserine (thiol)lyase; ST, sulfate transporter; SiR, sulfite reductase.

\section{Crosstalk of Ethylene with $\mathrm{N}$ and $\mathrm{S}$ in Salt Tolerance}

Interaction-outcomes of ETH with uptake, assimilation of the major mineral elements can contribute in improving plant growth and development under abiotic stresses [10,16]. Deficiency of both $\mathrm{N}$ and $\mathrm{S}$ is established in the world soils. Hence, maximizing their utilization efficiency in plants is imperative for crop improvement. Studies have enlightened the relation between S-deficiency and ETH-biosynthesis. ETH could ameliorate and regulate S-deficiency in plants [142]. Despite role of N and S in constituting Cys, required for the synthesis of GSH and Met precursor of ETH biosynthesis, the influence of $\mathrm{N}$ and $\mathrm{S}$ on ETH signaling is meager. As a part of SAM, Met can act as a regulatory molecule 
in ETH synthesis. The Met pathway is sensitive to salt stress; however, the level of SAM synthase is enhanced significantly under salt stress [9]. In assimilation of $\mathrm{N}$, incorporation of NR into amino acids occurs via GOGAT pathways. Many of these amino acids are involved in ETH-biosynthesis control. Moreover, in addition to increasing N-assimilation, ETH has also been found to regulate proline production in plants under optimum or stress conditions [10,127].

Exogenous ETH through ethephon (ETH releasing compound) can increase N-assimilation and photosynthesis in plants subjected to different levels of $\mathrm{N}$ [127]. S-nutrition can modulate plant stress responses by increasing ETH production. Excess S-mediated plant salt tolerance involved ETH, where inhibition of ETH biosynthesis counteracted the effects of $S$ excess on salt stress mitigation [16]. Moreover, the cross-talk between GSH and ETH signaling was proposed under Cd and drought stress $[163,164]$. However, this is not the only link between ETH synthesis and S. Under S-limited condition, the transcription factor ETH insensitive-like 3 gene regulates many S-deficiency responsive genes [165]. Figure 3 summarizes the interaction of ETH with $\mathrm{N}$ and $\mathrm{S}$.

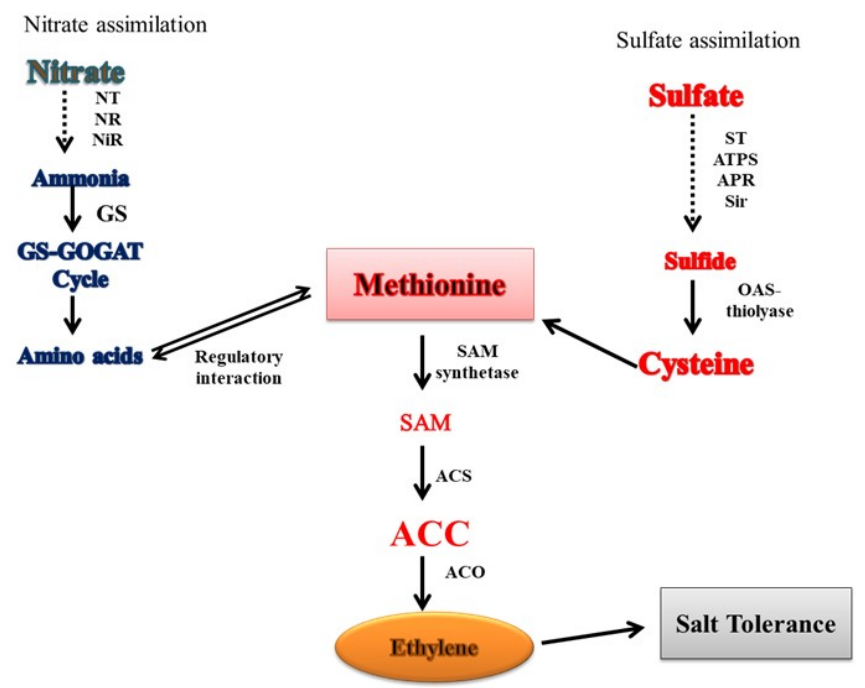

Figure 3. Regulatory interaction between nitrogen $(\mathrm{N})$ and sulfur $(\mathrm{S})$ assimilation and ethylene (ETH) biosynthesis linked with salt stress tolerance. ACC, 1-amino cyclopropane carboxylic acid synthase; ACO, 1-amino cyclopropane carboxylic acid oxidase; APR, adenosine 5'phosphosulfate reductase; ATP-S, ATP sulfurylase; GS, glutamine synthetase; NR, nitrate reductase; NiR, nitrite reductase; NT, nitrate transporter; ST, sulfate transporter; SiR, sulfite reductase; OAS-TL, O-acetylserine (thiol)lyase; SAM, S-adenosyl methionine.

\section{Conclusions: Bridging the Gaps in Understanding Salinity Tolerance}

The review emphasizes that salt-induced consequences in plants are primarily due to the excess overproduction of ROS resulting in disturbance in plant metabolism and eventually loss of photosynthetic productivity. The appraisal of the studies conducted has shown that plants execute various mechanisms as possible defense strategies to respond the adverse stress conditions. The management of mineral nutrients $\mathrm{N}$ or S-mediated regulation serves as a major determinant for depicting salt stress tolerance. Assimilation of $\mathrm{N}$ or $\mathrm{S}$ leads to the synthesis of Cys that serves as a precursor for the synthesis of a tripeptide GSH which plays a key role in the protection of plants against salt stress. Additionally, the supplementation of $\mathrm{N}$ and $\mathrm{S}$ and exogenously applied phytohormones prove beneficial for the physiology and metabolism of plants under salt stress, by regulating various metabolic processes as a function of antioxidative defense enzymes. Antioxidants defense system has a constructive function in controlling salt stress in scavenging ROS. Enhanced level of antioxidants enzymes in plants may provide a shield against salt stress through molecular approaches. The literature discussed provides insight on the effects 
of phytohormones signaling on the regulation of $\mathrm{N}$ and $\mathrm{S}$ assimilation, GSH synthesis, physiological processes, and productivity of crop species under abiotic stress in general and salt stress in picky. Moreover, diverse studies illustrate the involvement of NO and ETH in providing protection against various environmental stresses, only meager studies discuss the interaction of $\mathrm{NO}$ and ETH with $\mathrm{N}$ and $\mathrm{S}$ with respect to the salt stress. This review also presented a critical crosstalk on $\mathrm{NO} / \mathrm{ETH}$, assimilation of $\mathrm{N}$ and $\mathrm{S}$, and salt stress (Figure 4).

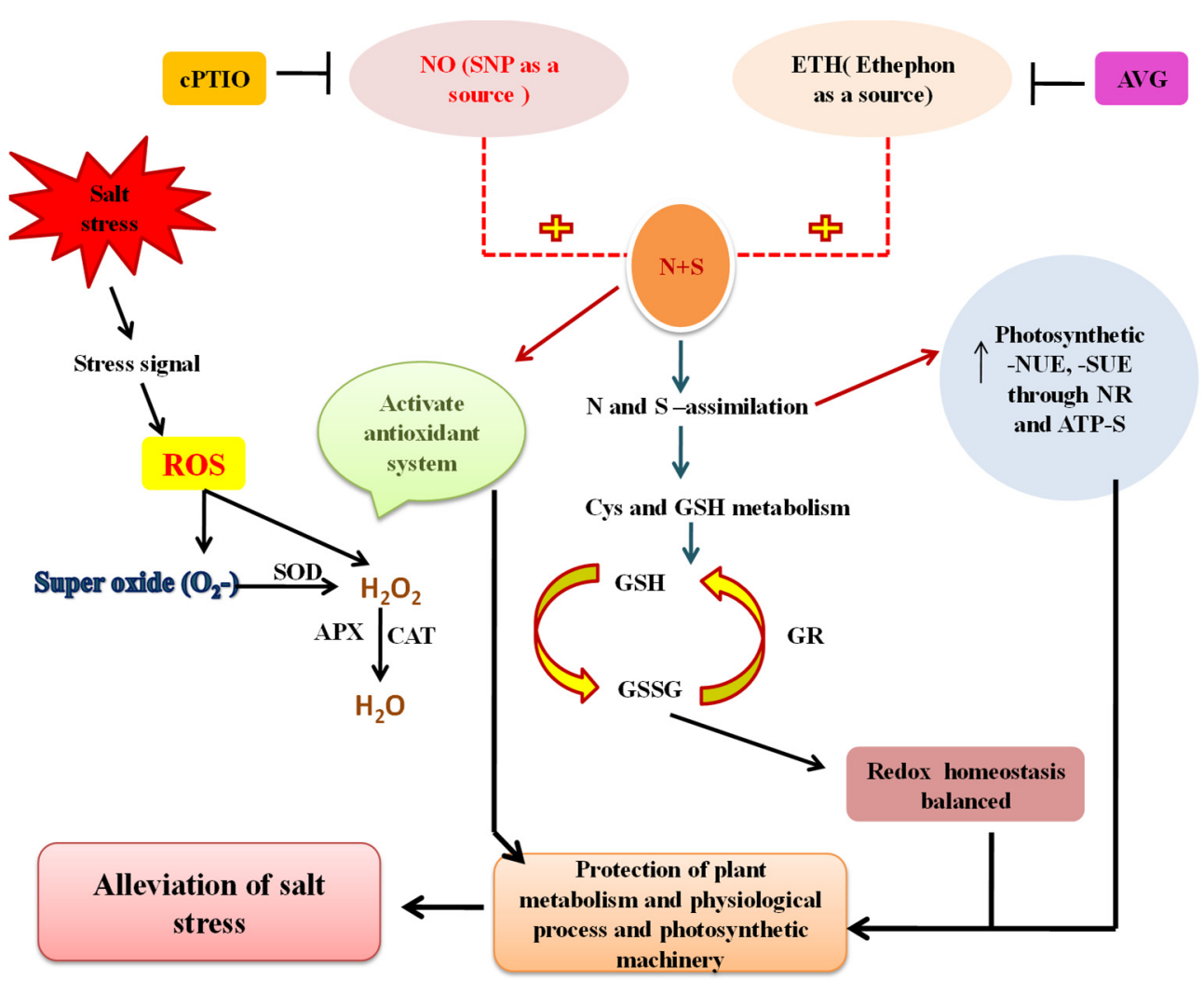

Figure 4. Summary of the major outcomes. The involvement of NO/ETH with supplementation of $\mathrm{N}$ and $\mathrm{S}$ in alleviation toxicity of salt stress. APX, ascorbate peroxidase; AVG, 1-aminoethoxy vinyl glycine; ETH, ethylene; cPTIO, 4-(carboxyphenyl)-4,4,5,5-tetramethylimidazoline-1-oxy-3-oxide; CAT, catalase; Cys, cysteine; GR, glutathione reductase; GSH, reduced glutathione; GSSG, oxidized glutathione; N, nitrogen; NO, nitric oxide; NUE, nitrogen use efficiency; S, sulfur; SOD, superoxide dismutase; SUE, sulfur use efficiency.

The synergistic relationship of $\mathrm{N}$ and $\mathrm{S}$ plus phytohormone (ETH/NO) could control plant metabolism and crop yields under salt stress. The interaction between NO/ETH, and $\mathrm{N}$ - and S-assimilation, and their assimilatory products makes this approach novel. Thus, the study of the interaction between NO/ETH and N and S is essential as efficient utilization of these nutrients under the influence of these phytohormones will not only benefit photosynthetic and yield potential of plants, but also will result in salt tolerance through the higher synthesis of metabolites. Additionally, the loss of nutrients will be reduced, thereby saving our expenditure on the production of these fertilizers.

Author Contributions: Conceptualization, B.J. and N.A.K.; validation, B.J., M.F. and N.I.; resources, B.J., F.R., Z.S. and A.M.; writing-original draft preparation, B.J. and N.A.A.; writing-review and editing, N.A.K., N.I. and M.F.; supervision, N.A.K. All authors have read and agreed to the published version of the manuscript.

Funding: This research received no external funding.

Institutional Review Board Statement: Not applicable. 
Informed Consent Statement: Not applicable.

Data Availability Statement: Not applicable.

Conflicts of Interest: The authors declare no conflict of interest.

\section{References}

1. Sehar, Z.; Masood, A.; Khan, N.A. Nitric oxide reverses glucose-mediated photosynthetic repression in wheat (Triticum aestivum L.) under salt stress. Environ. Exp. Bot. 2019, 161, 277-289. [CrossRef]

2. Jahan, B.; Al Ajmi, M.F.; Rehman, M.T.; Khan, N.A. Treatment of nitric oxide supplemented with nitrogen and sulfur regulates photosynthetic performance and stomatal behavior in mustard under salt stress. Physiol. Plant. 2020, 168, 490-510. [PubMed]

3. Khanna, R.R.; Jahan, B.; Iqbal, N.; Khan, N.A.; AlAjmi, M.F.; Rehman, M.T.; Khan, M.I.R. GABA reverses salt-inhibited photosynthetic and growth responses through its influence on NO-mediated nitrogen-sulfur assimilation and antioxidant system in wheat. J. Biotech. 2021, 325, 73-82. [CrossRef]

4. Machado, R.M.A.; Serralheiro, R.P. Soil salinity: Effect on vegetable crop growth. Management practices to prevent and mitigate soil salinization. Horticulturae 2017, 3, 30. [CrossRef]

5. Hasanuzzaman, M.; Nahar, K.; Alam, M.; Bhowmik, P.C.; Hossain, M.; Rahman, M.M.; Fujita, M. Potential use of halophytes to remediate saline soils. Biomed. Res. Int. 2014, 2014, 589341. [CrossRef]

6. Kumar, P.; Sharma, P.K. Soil salinity and food security in India. Front. Sustain. Syst. 2020, 4, 533781. [CrossRef]

7. Chokshi, K.; Pancha, I.; Ghosh, A.; Mishra, S. Salinity induced oxidative stress alters the physiological responses and improves the biofuel potential of green microalgae Acutodesmus dimorphus. Bioresour. Technol. 2017, 244, 1376-1383. [CrossRef]

8. Kamran, M.; Parveen, A.; Ahmar, S.; Malik, Z.; Hussain, S.; Chattha, M.S.; Chen, J.T. An overview of hazardous impacts of soil salinity in crops, tolerance mechanisms, and amelioration through selenium supplementation. Int. J. Mol. Sci. 2020, $21,148$. [CrossRef]

9. Fatma, M.; Khan, M.I.R.; Masood, A.; Khan, N.A. Coordinate changes in assimilatory sulfate reduction are correlated to salt tolerance: Involvement of phytohormones. Annu. Res. Rev. Biol. 2013, 3, 267-295.

10. Jahan, B.; Iqbal, N.; Fatma, M.; Sehar, Z.; Masood, A.; Sofo, A.; D’Ippolito, I.; Khan, N.A. Ethylene supplementation combined with split application of nitrogen and sulfur protects salt-inhibited photosynthesis through optimization of proline metabolism and antioxidant system in mustard (Brassica juncea L.). Plants 2021, 10, 1303. [CrossRef]

11. Liu, C.; Zhao, X.; Yan, J.; Yuan, Z.; Gu, M. Effects of salt stress on growth, photosynthesis, and mineral nutrients of 18 pomegranate (Punica granatum) cultivars. Agronomy 2020, 10, 27. [CrossRef]

12. Qiao, Y.; Yin, L.; Wang, B.; Ke, Q.; Deng, X.; Wang, S. Melatonin promotes plant growth by increasing nitrogen uptake and assimilation under nitrogen deficient condition in winter wheat. Plant Physiol. Biochem. 2019, 139, 342-349. [CrossRef] [PubMed]

13. Xu, G.; Fan, X.; Miller, A.J. Plant nitrogen assimilation and use efficiency. Annu. Rev. Plant Biol. 2012, 63, 153-182. [CrossRef] [PubMed]

14. Wang, Y.; Wang, M.; Li, Y.; Wu, A.; Huang, J. Effects of arbuscular mycorrhizal fungi on growth and nitrogen uptake of Chrysanthemum morifolium under salt stress. PLoS ONE 2018, 13, e0196408. [CrossRef]

15. Hussain, S.J.; Khan, N.A.; Anjum, N.A.; Masood, A.; Khan, M.I.R. Mechanistic elucidation of salicylic acid and sulphur-induced defence systems, nitrogen metabolism, photosynthetic, and growth potential of mungbean (Vigna radiata) under salt stress. J. Plant Growth Regul. 2021, 40, 1000-1016. [CrossRef]

16. Fatma, M.; Iqbal, N.; Gautam, H.; Sehar, Z.; Sofo, A.; D'Ippolito, I.; Khan, N.A. Ethylene and sulfur coordinately modulate the antioxidant system and ABA accumulation in mustard plants under salt stress. Plants 2021, 10, 180. [CrossRef]

17. Fatma, M.; Masood, A.; Per, T.S.; Khan, N.A. Nitric oxide alleviates salt stress inhibited photosynthetic performance by interacting with sulfur assimilation in mustard. Front. Plant Sci. 2016, 7, 521. [CrossRef]

18. Asgher, M.; Per, T.S.; Masood, A.; Fatma, M.; Freschi, L.; Corpas, F.J.; Khan, N.A. Nitric oxide signaling and its crosstalk with other plant growth regulators in plant responses to abiotic stress. Environ. Sci. Pollut. Res. 2017, 24, 2273-2285. [CrossRef]

19. Per, T.S.; Khan, N.A.; Reddy, P.S.; Masood, A.; Hasanuzzaman, M.; Khan, M.I.R.; Anjum, N.A. Approaches in modulating proline metabolism in plants for salt and drought stress tolerance, Phytohormones, mineral nutrients and transgenics. Plant Physiol. Biochem. 2017, 115, 126-140. [CrossRef]

20. Hasanuzzaman, M.; Oku, H.; Nahar, K.; Bhuyan, M.B.; Al Mahmud, J.; Baluska, F.; Fujita, M. Nitric oxide-induced salt stress tolerance in plants: ROS metabolism, signaling, and molecular interactions. Plant Biotechnol. Rep. 2018, 12, 77-92. [CrossRef]

21. Borbély, P.; Poór, P.; Tari, I. Changes in physiological and photosynthetic parameters in tomato of different ethylene status under salt stress: Effects of exogenous 1-aminocyclopropane-1-carboxylic acid treatment and the inhibition of ethylene signalling. Plant Physiol. Biochem. 2020, 156, 345-356. [CrossRef] [PubMed]

22. Sehar, Z.; Iqbal, N.; Khan, M.I.R.; Masood, A.; Rehman, M.T.; Hussain, A.; AlAjmi, M.F.; Ahmad, A.; Khan, N.A. Ethylene reduces glucose sensitivity and reverses photosynthetic repression through optimization of glutathione production in salt-stressed wheat (Triticum aestivum L.). Sci. Rep. 2021, 11, 1-12.

23. Iqbal, N.; Umar, S.; Khan, N.A. Nitrogen availability regulates proline and ethylene production and alleviates salinity stress in mustard (Brassica juncea). J. Plant Physiol. 2015, 178, 84-91. [CrossRef] [PubMed] 
24. Wicke, B.; Smeets, E.; Dornburg, V.; Vashev, B.; Gaiser, T.; Turkenburg, W.; Faaij, A. The global technical and economic potential of bioenergy from salt-affected soils. Energy Environ. Sci. 2011, 4, 2669-2681. [CrossRef]

25. Rasool, S.; Hameed, A.; Azooz, M.M.; Siddiqi, T.O.; Ahmad, P. Salt stress: Causes, types and responses of plants. In Ecophysiology and Responses of Plants under Salt Stress; Ahmad, P., Azooz, M.M., Prasad, M.N.V., Eds.; Springer Science \& Business Media: New York, NY, USA, 2012; pp. 1-24.

26. Xu, G.Y.; Rocha, P.S.; Wang, M.L.; Xu, M.L.; Cui, Y.C.; Li, L.Y.; Zhu, Y.X.; Xia, X. A novel rice calmodulin-like gene, OsMSR2, enhances drought and salt tolerance and increases ABA sensitivity in Arabidopsis. Planta 2011, 234, 47-59. [CrossRef]

27. Akbarimoghaddam, H.; Galavi, M.; Ghanbari, A.; Panjehkeh, N. Salinity effects on seed germination and seedling growth of bread wheat cultivars. Trakia J. Sci. 2011, 9, 43-50.

28. Sharma, P.; Sardana, V.; Banga, S.S. Salt tolerance of Indian mustard (Brassicajuncea L.) at germination and early seedling growth. Environ. Exp. Biol. 2013, 11, 39-46.

29. Chowdhury, F.T.; Halim, M.A.; Hossain, F.; Akhtar, N. Effects of sodium chloride on germination and seedling growth of Sunflower (Helianthus annuus L.). Jahangirnagar Uni. J. Biol Sci. 2018, 7, 35-44. [CrossRef]

30. Rahneshan, Z.; Nasibi, F.; Moghadam, A.A. Effects of salinity stress on some growth, physiological, biochemical parameters and nutrients in two pistachio (Pistaciavera L.) rootstocks. J. Plant Interact. 2018, 13, 73-82. [CrossRef]

31. Jaarsma, R.; de Vries, R.S.; de Boer, A.H. Effect of salt stress on growth, $\mathrm{Na}^{+}$accumulation and proline metabolism in potato (Solanum tuberosum) cultivars. PLoS ONE 2013, 8, e60183. [CrossRef]

32. Faghire, M.; Mohamed, F.; Taoufiq, K.; Fghire, R.; Bargaz, A.; Mandri, B.; Oufdou, K.; Laury, A.; Drevon, J.J.; Ghoulam, C. Genotypic variation of nodules' enzymatic activities in symbiotic nitrogen fixation among common bean (Phaseolus vulgaris L.) genotypes grown under salinity constraint. Symbiosis 2013, 60, 115-122. [CrossRef]

33. Latrach, L.; Farissi, M.; Mouradi, M.; Makoudi, B.; Bouizgaren, A.; Ghoulam, C. Growth and nodulation of alfalfa-rhizobia symbiosis under salinity: Electrolyte leakage, stomatal conductance, and chlorophyll fluorescence. Turk. J. Agric. For. 2014, 38, 320-326. [CrossRef]

34. Javid, M.; Ford, R.; Norton, R.; Nicolas, M. Sodium and boron exclusion in two Brassica juncea cultivars exposed to the combined treatments of salinity and boron at moderate alkalinity. Biologia 2014, 69, 1157-1163. [CrossRef]

35. Ghanem, A.E.; Mohamed, E.; Kasem, A.M.; El-Ghamery, A.A. Differential salt tolerance strategies in three halophytes from the same ecological habitat: Augmentation of antioxidant enzymes and compounds. Plants 2021, 10, 1100. [CrossRef]

36. Li, H.; Chang, J.; Chen, H.; Wang, Z.; Gu, X.; Wei, C.; Zhang, Y.; Ma, J.; Yang, J.; Zhang, X. Exogenous melatonin confers salt stress tolerance to watermelon by improving photosynthesis and redox homeostasis. Front. Plant Sci. 2017, 8, 295. [CrossRef]

37. Mahdieh, M.; Habibollahi, N.; Amirjani, M.R.; Abnosi, M.H.; Ghorbanpour, M. Exogenous silicon nutrition ameliorates saltinduced stress by improving growth and efficiency of PSII in Oryza sativa L. cultivars. J. Soil Sci. Plant Nutr. 2015, 15, 1050-1060. [CrossRef]

38. Jiang, C.; Johkan, M.; Hohjo, M.; Tsukagoshi, S.; Maruo, T. A correlation analysis on chlorophyll content and SPAD value in tomato leaves. Hortic. Res. 2017, 71, 37-42.

39. Mehta, P.; Jajoo, A.; Mathur, S.; Bharti, S. Chlorophyll a fluorescence study revealing effects of high salt stress on Photosystem II in wheat leaves. Plant Physiol. Biochem. 2010, 48, 16-20. [CrossRef]

40. Kalaji, H.M.; Bosa, K.; Kościelniak, J.; Żuk-Gołaszewska, K. Effects of salt stress on photosystem II efficiency and $\mathrm{CO}_{2}$ assimilation of two Syrian barley landraces. Environ. Exp. Bot. 2011, 73, 64-72. [CrossRef]

41. Fatma, M.; Iqbal, N.; Sehar, Z.; Alyemeni, M.N.; Kaushik, P.; Khan, N.A.; Ahmad, P. Methyl jasmonate protects the ps ii system by maintaining the stability of chloroplast $\mathrm{d} 1$ protein and accelerating enzymatic antioxidants in heat-stressed wheat plants. Antioxidants 2021, 10, 1216. [CrossRef] [PubMed]

42. Singh, M.; Singh, V.P.; Prasad, S.M. Responses of photosynthesis, nitrogen and proline metabolism to salinity stress in Solanum lycopersicum under different levels of nitrogen supplementation. Plant Physiol. Biochem. 2016, 109, 72-83. [CrossRef]

43. Nxele, X.; Klein, A.; Ndimba, B.K. Drought and salinity stress alters ROS accumulation, water retention, and osmolyte content in sorghum plants. S. Afr. J. Bot. 2017, 108, 261-266. [CrossRef]

44. Aldesuquy, H.; Baka, Z.; Mickky, B. Kinetin and spermine mediated induction of salt tolerance in wheat plants: Leaf area, photosynthesis and chloroplast ultrastructure of flag leaf at ear emergence. Egypt. J. Basic Appl. Sci. 2014, 1, 77-87. [CrossRef]

45. Wu, X.; Zhu, Z.; Li, X.; Zha, D. Effects of cytokinin on photosynthetic gas exchange, chlorophyll fluorescence parameters and antioxidative system in seedlings of eggplant (Solanum melongena L.) under salinity stress. Acta Physiol. Plant. 2012, 34, $2105-2114$. [CrossRef]

46. Hussain, S.; Bai, Z.; Huang, J.; Cao, X.; Zhu, L.; Zhu, C.; Zhang, J. 1-Methylcyclopropene modulates physiological, biochemical, and antioxidant responses of rice to different salt stress levels. Front. Plant Sci. 2019, 10, 124. [CrossRef] [PubMed]

47. Khalid, A.; Athar, H.U.R.; Zafar, Z.U.; Akram, A.; Hussain, K.; Manzoor, H.; Al-Qurainy, F.; Ashraf, M. Photosynthetic capacity of canola (Brassica napus L.) plants as affected by glycinebetaine under salt stress. J. Appl. Bot. Food Qual. 2015, 88, 78-86.

48. Anjum, N.A.; Sofo, A.; Scopa, A.; Roychoudhury, A.; Gill, S.S.; Iqbal, M.; Ahmad, I.; Lukatkin, A.S.; Pereira, E.; Durate, A.C.; et al. Lipids and proteins-major targets of oxidative modifications in abiotic stressed plants. Environ. Sci. Pollut. Res. 2015, 22, 4099-4121. [CrossRef]

49. Tammam, A.A.; Fakhry, E.M.; El-Sheekh, M. Effect of salt stress on antioxidant system and the metabolism of the reactive oxygen species in Dunaliellasalina and Dunaliellatertiolecta. Afr. J. Biotechnol. 2011, 10, 3795-3808. 
50. AbdElgawad, H.; Zinta, G.; Hegab, M.M.; Pandey, R.; Asard, H.; Abuelsoud, W. High salinity induces different oxidative stress and antioxidant responses in maize seedlings organs. Front. Plant Sci. 2016, 7, 276. [CrossRef] [PubMed]

51. Sofo, A.; Scopa, A.; Nuzzaci, M.; Vitti, A. Ascorbate peroxidase and catalase activities and their genetic regulation in plants subjected to drought and salinity stresses. Int. J. Mol. Sci. 2015, 16, 13561-13578. [CrossRef]

52. Weisany, W.; Sohrabi, Y.; Heidari, G.; Siosemardeh, A.; Ghassemi-Golezani, K. Changes in antioxidant enzymes activity and plant performance by salinity stress and zinc application in soybean ('Glycine max' L.). Plant Omics 2012, 5, 60-67.

53. Patel, A.D.; Jadeja, H.; Pandey, A.M. Effect of salinization of soil on growth, water status and nutrient accumulation in seedlings of Acacia auriculiformis (Fabaceae). J. Plant Nutr. 2010, 33, 914-932. [CrossRef]

54. Parihar, P.; Singh, S.; Singh, R.; Singh, V.P.; Prasad, S.M. Effect of salinity stress on plants and its tolerance strategies, a review. Environ. Sci. Pollut. Res. 2015, 22, 4056-4075. [CrossRef] [PubMed]

55. Ashraf, M.; Shahzad, S.M.; Imtiaz, M.; Rizwan, M.S.; Arif, M.S.; Kausar, R. Nitrogen nutrition and adaptation of glycophytes to saline environment: A review. Arch. Agron. Soil Sci. 2018, 64, 1181-1206. [CrossRef]

56. Rasheed, F.; Anjum, N.A.; Masood, A.; Sofo, A.; Khan, N.A. The key roles of salicylic acid and sulfur in plant salinity stress tolerance. J. Plant Growth Regul. 2020, 1-14. [CrossRef]

57. Wu, H.; Zhang, X.; Giraldo, J.P.; Shabala, S. It is not all about sodium: Revealing tissue specificity and signalling roles of potassium in plant responses to salt stress. Plant Soil 2018, 431, 1-17. [CrossRef]

58. Wu, H.; Zhu, M.; Shabala, L.; Zhou, M.; Shabala, S. $\mathrm{K}^{+}$retention in leaf mesophyll, an overlooked component of salinity tolerance mechanism: A case study for barley. J. Integr. Plant Biol. 2015, 57, 171-185. [CrossRef]

59. Tabassum, T.; Farooq, M.; Ahmad, R.; Zohaib, A.; Wahid, A. Seed priming and transgenerational drought memory improves tolerance against salt stress in bread wheat. Plant Physiol. Biochem. 2017, 118, 362-369. [CrossRef]

60. Fahad, S.; Hussain, S.; Saud, S.; Hassan, S.; Tanveer, M.; Ihsan, M.Z.; Shah, A.N.; Ullah, A.; Khan, F.; Ullah, S.; et al. A combined application of biochar and phosphorus alleviates heat-induced adversities on physiological, agronomical and quality attributes of rice. Plant Physiol. Biochem. 2016, 103, 191-198. [CrossRef]

61. Tang, H.; Niu, L.; Wei, J.; Chen, X.; Chen, Y. Phosphorus limitation improved salt tolerance in maize through tissue mass density increase, osmolytes accumulation, and $\mathrm{Na}^{+}$uptake inhibition. Front. Plant Sci. 2019, 10, 856. [CrossRef]

62. Zörb, C.; Geilfus, C.M.; Dietz, K.J. Salinity and crop yield. Plant Biol. 2019, 21, 31-38. [CrossRef]

63. Wani, A.S.; Ahmad, A.; Hayat, S.; Tahir, I. Epibrassinolide and proline alleviate the photosynthetic and yield inhibition under salt stress by acting on antioxidant system in mustard. Plant Physiol. Biochem. 2019, 135, 385-394. [CrossRef] [PubMed]

64. Hasanuzzaman, M.; Nahar, K.; Fujita, M. Plant response to salt stress and role of exogenous protectants to mitigate salt-induced damages. In Ecophysiology and Responses of Plants under Salt Stress; Ahmad, P., Azooz, M.M., Prasad, M.N.V., Eds.; Springer Science \& Business Media: New York, NY, USA, 2012; pp. 25-87.

65. Breseghello, F.; Coelho, A.S.G. Traditional and modern plant breeding methods with examples in rice (Oryza sativa L.). J. Agric. Food Chem. 2013, 61, 8277-8286. [CrossRef] [PubMed]

66. Ashfaque, F.; Khan, M.I.R.; Khan, N.A. Exogenously applied $\mathrm{H}_{2} \mathrm{O}_{2}$ promotes proline accumulation, water relations, photosynthetic efficiency and growth of wheat (Triticumaestivum L.) under salt stress. Annu. Res. Rev. Biol. 2014, 4, 105-120. [CrossRef]

67. Nazar, R.; Iqbal, N.; Syeed, S.; Khan, N.A. Salicylic acid alleviates decreases in photosynthesis under salt stress by enhancing nitrogen and sulfur assimilation and antioxidant metabolism differentially in two mungbean cultivars. J. Plant Physiol. 2011, 168, 807-815. [CrossRef] [PubMed]

68. Astolfi, S.; Zuchi, S. Adequate S supply protects barley plants from adverse effects of salinity stress by increasing thiol contents. Acta Physiol. Plant. 2013, 35, 175-181. [CrossRef]

69. The, C.Y.; Shaharuddin, N.A.; Ho, C.L.; Mahmood, M. Exogenous proline significantly affects the plant growth and nitrogen assimilation enzymes activities in rice (Oryza sativa) under salt stress. Acta Physiol. Plant. 2016, 38, 151.

70. Fuertes-Mendizábal, T.; Bastías, E.I.; González-Murua, C.; González-Moro, M. Nitrogen assimilation in the highly salt and boron-tolerant ecotype Zea mays L. Amylacea. Plants 2020, 9, 322. [CrossRef] [PubMed]

71. Goel, P.; Singh, A.K. Abiotic stresses downregulate key genes involved in nitrogen uptake and assimilation in Brassica juncea L. PLoS ONE 2015, 10, e0143645. [CrossRef]

72. Ahanger, M.A.; Qin, C.; Begum, N.; Maodong, Q.; Dong, X.X.; El-Esawi, M.; El-Sheikh, M.A.; Alatar, A.A.; Zhang, L. Nitrogen availability prevents oxidative effects of salinity on wheat growth and photosynthesis by up-regulating the antioxidants and osmolytes metabolism.; and secondary metabolite accumulation. BMC Plant Biol. 2019, 19, 479. [CrossRef]

73. Singh, A.; Hussain, I.; Singh, N.B.; Singh, H. Uptake, translocation and impact of green synthesized nanoceria on growth and antioxidant enzymes activity of Solanum lycopersicum L. Ecotoxicol. Environ. Saf. 2019, 182, 109410. [CrossRef] [PubMed]

74. Coelho, D.G.; Miranda, R.D.S.; Paula-Marinho, S.D.O.; de Carvalho, H.H.; Prisco, J.T.; Gomes-Filho, E. Ammonium nutrition modulates $\mathrm{K}^{+}$and $\mathrm{N}$ uptake, transport and accumulation during salt stress acclimation of sorghum plants. Arch. Agron. Soil Sci. 2020, 66, 1991-2004. [CrossRef]

75. Soliman, M.; Elkelish, A.; Souad, T.; Alhaithloul, H.; Farooq, M. Brassinosteroid seed priming with nitrogen supplementation improves salt tolerance in soybean. Physiol. Mol. Biol. Plants 2020, 26, 501-511. [CrossRef] [PubMed]

76. Per, T.S.; Khan, N.A.; Masood, A.; Fatma, M. Methyl jasmonate alleviates cadmium-induced photosynthetic damages through increased S-assimilation and glutathione production in mustard. Front. Plant Sci. 2016, 7, 1933. [CrossRef] 
77. Fatma, M.; Masood, A.; Per, T.S.; Rasheed, F.; Khan, N.A. Interplay between nitric oxide and sulfur assimilation in salt tolerance in plants. Crop J. 2016, 4, 153-161. [CrossRef]

78. Fatma, M.; Asgher, M.; Masood, A.; Khan, N.A. Excess sulfur supplementation improves photosynthesis and growth in mustard under salt stress through increased production of glutathione. Environ. Exp. Bot. 2014, 107, 55-63. [CrossRef]

79. Seth, C.S.; Remans, T.; Keunen, E.; Jozefczak, M.; Gielen, H.; Opdenakker, K.; Cuypers, A. Phytoextraction of toxic metals: A central role for glutathione. Plant Cell Environ. 2012, 35, 334-346. [CrossRef]

80. Kumar, D.; Chattopadhyay, S. Glutathione modulates the expression of heat shock proteins via the transcription factors BZIP10 and MYB21 in Arabidopsis. J. Exp. Bot. 2018, 69, 3729-3743. [CrossRef]

81. Iqbal, N.; Umar, S.; Khan, N.A.; Corpas, F.J. Nitric oxide and hydrogen sulfide coordinately reduce glucose sensitivity and decrease oxidative stress via ascorbate-glutathione cycle in heat-stressed wheat (Triticum aestivum L.) plants. Antioxidants 2021, 10, 108. [CrossRef]

82. Mera, R.; Torres, E.; Abalde, J. Sulphate.; more than a nutrient; protects the microalga Chlamydomonas moewusii from cadmium toxicity. Aquat. Toxicol. 2014, 148, 92-103. [CrossRef] [PubMed]

83. Romero, T.C.; Nortes, T.P.A.; Pedrero, S.F.; Mounzer, O.; Alarcón, C.J.J.; Bayona, G.J.M.; Nicolás, N.E. Assessment of the viability of using saline reclaimed water in grapefruit in medium to long term. Span. J. Agric. Res. 2014, 12, 1137-1148. [CrossRef]

84. Riffat, A.L.I.A.; Sajid, M.; Ahmad, A. Alleviation of adverse effects of salt stress on growth og maize Zea mays L. by sulfur supplementation. Pak. J. Bot. 2020, 523, 763-773.

85. de Souza Freitas, W.E.; de Oliveira, A.B.; Mesquita, R.O.; de Carvalho, H.H.; Prisco, J.T.; Gomes-Filho, E. Sulfur-induced salinity tolerance in lettuce is due to a better $\mathrm{P}$ and $\mathrm{K}$ uptake.; lower $\mathrm{Na} / \mathrm{K}$ ratio and an efficient antioxidative defense system. Sci. Hortic. 2019, 257, 108764. [CrossRef]

86. Aziz, A.; Ashraf, M.; Sikandar, S.; Asif, M.; Akhtar, N.; Shahzad, S.M.; Babar, B.H. Optimizing sulfur for improving salt tolerance of sunflower Helianthus annuus L. Soil Environ. 2019, 38, 222-233. [CrossRef]

87. Coleto, I.; de la Peña, M.; Rodríguez-Escalante, J.; Bejarano, I.; Glauser, G.; Aparicio-Tejo, P.M.; Marino, D. Leaves play a central role in the adaptation of nitrogen and sulfur metabolism to ammonium nutrition in oilseed rape Brassica napus. BMC Plant Biol. 2017, 17, 1-13. [CrossRef] [PubMed]

88. Jobe, T.O.; Zenzen, I.; Rahimzadeh, K.P.; Kopriva, S. Integration of sulfate assimilation with carbon and nitrogen metabolism in transition from C3 to C4 photosynthesis. J. Exp. Bot. 2019, 70, 4211-4221. [CrossRef]

89. Prodhan, M.A.; Finnegan, P.M.; Lambers, H. How does evolution in phosphorus-impoverished landscapes impact plant nitrogen and sulfur assimilation? Trends Plant Sci. 2019, 24, 69-82. [CrossRef]

90. Rais, L.; Masood, A.; Inam, A.; Khan, N. Sulfur and nitrogen co-ordinately improve photosynthetic efficiency, growth and proline accumulation in two cultivars of mustard under salt stress. J. Plant Biochem. Physiol. 2013, 1. [CrossRef]

91. Zhang, N.N.; Zou, H.; Lin, X.Y.; Pan, Q.; Zhang, W.Q.; Zhang, J.H.; Chen, J. Hydrogen sulfide and rhizobia synergistically regulate nitrogen $\mathrm{N}$ assimilation and remobilization during $\mathrm{N}$ deficiency-induced senescence in soybean. Plant Cell Environ. 2020, 43, 1130-1147. [CrossRef] [PubMed]

92. Lancaster, J.R., Jr. Nitric oxide: A brief overview of chemical and physical properties relevant to therapeutic applications. Future Sci. OA 2015, 1. [CrossRef]

93. Nabi, R.B.S.; Tayade, R.; Hussain, A.; Kulkarni, K.P.; Imran, Q.M.; Mun, B.G.; Yun, B.W. Nitric oxide regulates plant responses to drought, salinity, and heavy metal stress. Environ. Exp. Bot. 2019, 161, 120-133. [CrossRef]

94. Fancy, N.N.; Bahlmann, A.K.; Loake, G.J. Nitric oxide functions in plant abiotic stress. Plant Cell Environ. 2017, 40, 462-472. [CrossRef] [PubMed]

95. Akram, N.A.; Iqbal, M.; Muhammad, A.; Ashraf, M.; Al-Qurainy, F.; Shafiq, S. Aminolevulinic acid and nitric oxide regulate oxidative defense and secondary metabolisms in canola (Brassica napus L.) under drought stress. Protoplasma 2018, 255, 163-174. [CrossRef] [PubMed]

96. Ahmad, P.; Abass, A.M.; Nasser, A.M.; Wijaya, L.; Alam, P.; Ashraf, M. Mitigation of sodium chloride toxicity in Solanum lycopersicum L. by supplementation of jasmonic acid and nitric oxide. J. Plant Interact. 2018, 13, 64-72. [CrossRef]

97. Tian, X.; He, M.; Wang, Z.; Zhang, J.; Song, Y.; He, Z.; Dong, Y. Application of nitric oxide and calcium nitrate enhances tolerance of wheat seedlings to salt stress. Plant Growth Regul. 2015, 77, 343-356. [CrossRef]

98. Gaupels, F.; Kuruthukulangarakoola, G.T.; Durner, J. Upstream and downstream signals of nitric oxide in pathogen defence. Curr. Opin. Plant Biol. 2011, 14, 707-714. [CrossRef]

99. Martínez-Ruiz, A.; Cadenas, S.; Lamas, S. Nitric oxide signaling: Classical, less classical, and nonclassical mechanisms. Free Radic. Biol. Med. 2011, 51, 17-29. [CrossRef]

100. Corpas, F.J.; González-Gordo, S.; Cañas, A.; Palma, J.M. Nitric oxide and hydrogen sulfide in plants, which comes first? J. Exp. Bot. 2019, 70, 4391-4404. [CrossRef]

101. Prochazkova, D.; Haisel, D.; Pavlikova, D. Nitric oxide biosynthesis in plants-the short overview. Plant Soil Environ. 2014, 60, 129-134. [CrossRef]

102. Planchet, E.; Kaiser, W.M. Nitric oxide NO detection by DAF fluorescence and chemiluminescence: A comparison using abiotic and biotic NO sources. J. Exp. Bot. 2006, 57, 3043-3055. [CrossRef]

103. Leterrier, M.; Airaki, M.; Palma, J.M.; Chaki, M.; Barroso, J.B.; Corpas, F.J. Arsenic triggers the nitric oxide (NO) and Snitrosoglutathione (GSNO) metabolism in Arabidopsis. Environ. Pollut. 2012, 166, 136-143. [CrossRef] 
104. Sharma, A.; Kapoor, D.; Wang, J.; Landi, M.; Zheng, B.; Yan, D.; Yuan, H. Nitric oxide mediated mechanisms adopted by plants to cope with salinity. Biol. Plant. 2020, 64, 512-518. [CrossRef]

105. Astier, J.; Gross, I.; Durner, J. Nitric oxide production in plants, an update. J. Exp. Bot. 2018, 69, 3401-3411. [CrossRef]

106. Gupta, K.J.; Fernie, A.R.; Kaiser, W.M.; van Dongen, J.T. On the origins of nitric oxide. Trends Plant Sci. 2011, 16, 160-168. [CrossRef]

107. Baudouin, E. The language of nitric oxide signalling. Plant Biol. 2011, 13, 233-242. [CrossRef]

108. Wang, Y.; Lin, A.; Loake, G.J.; Chu, C. $\mathrm{H}_{2} \mathrm{O}_{2}$-induced leaf cell death and the crosstalk of reactive nitric/oxygen species F. J. Integr. Plant Biol. 2013, 55, 202-208. [CrossRef] [PubMed]

109. Yu, S.; Wang, W.; Wang, B. Recent progress of salinity tolerance research in plants. Russ. J. Genet. 2012, 48, 497-505. [CrossRef]

110. Vishwakarma, A.; Wany, A.; Pandey, S.; Bulle, M.; Kumari, A.; Kishorekumar, R.; Gupta, K.J. Current approaches to measure nitric oxide in plants. J. Exp. Bot. 2019, 70, 4333-4343. [CrossRef] [PubMed]

111. Gould, K.S.; Lamotte, O.; Klinguer, A.; Pugin, A.; Wendehenne, D. Nitric oxide production in tobacco leaf cells, a generalized stress response? Plant Cell Environ. 2003, 26, 1851-1862. [CrossRef]

112. Mur, L.A.; Prats, E.; Pierre, S.; Hall, M.A.; Hebelstrup, K.H. Integrating nitric oxide into salicylic acid and jasmonic acid/ethylene plant defense pathways. Front. Plant Sci. 2013, 4, 215. [CrossRef]

113. Mata-Pérez, C.; Sánchez-Calvo, B.; Padilla, M.N.; Begara-Morales, J.C.; Valderrama, R.; Corpas, F.J.; Barroso, J.B. Nitro-fatty acids in plant signaling: New key mediators of nitric oxide metabolism. Redox Biol. 2017, 11, 554-561. [CrossRef] [PubMed]

114. Jagodzik, P.; Tajdel-Zielinska, M.; Ciesla, A.; Marczak, M.; Ludwikow, A. Mitogen-activated protein kinase cascades in plant hormone signaling. Front. Plant Sci. 2018, 9, 1387. [CrossRef] [PubMed]

115. Asai, S.; Ohta, K.; Yoshioka, H. MAPK signaling regulates nitric oxide and NADPH oxidase-dependent oxidative bursts in Ncotianabenthamiana. Plant Cell 2008, 20, 1390-11406. [CrossRef]

116. Gadelha, C.G.; de Souza Miranda, R.; Alencar, N.L.M.; Costa, J.H.; Prisco, J.T.; Gomes-Filho, E. Exogenous nitric oxide improves salt tolerance during establishment of Jatropha curcas seedlings by ameliorating oxidative damage and toxic ion accumulation. J. Plant Physiol. 2017, 212, 69-79. [CrossRef] [PubMed]

117. Liu, S.; Yang, R.; Pan, Y.; Ma, M.; Pan, J.; Zhao, Y.; Zhang, L. Nitric oxide contributes to minerals absorption.; proton pumps and hormone equilibrium under cadmium excess in Trifoliumrepens L. plants. Ecotoxicol. Environ. Saf. 2015, 119, 35-46. [CrossRef]

118. Arora, D.; Bhatla, S.C. Melatonin and nitric oxide regulate sunflower seedling growth under salt stress accompanying differential expression of $\mathrm{Cu} / \mathrm{Zn}$ SOD and Mn SOD. Free Radic. Biol. Med. 2017, 106, 315-328. [CrossRef]

119. Babaei, S.; Niknam, V.; Behmanesh, M. Comparative effects of nitric oxide and salicylic acid on salinity tolerance in saffron Crocus sativus. Plant Biosyst. Int. J. Plant Biol. 2021, 155, 73-82. [CrossRef]

120. Huang, J.; Wei, H.; Li, L.; Yu, S. Transcriptome analysis of nitric oxide-responsive genes in upland cotton Gossypiumhirsutum. PLOS ONE 2018, 13, e0192367.

121. Maslennikova, D.R.; Allagulova, C.R.; Fedorova, K.A.; Plotnikov, A.A.; Avalbaev, A.M.; Shakirova, F.M. Cytokinins contribute to realization of nitric oxide growth-stimulating and protective effects on wheat plants. Russ. J. Plant Physiol. 2017, 64, 665-671. [CrossRef]

122. León, J.; Castillo, M.C.; Coego, A.; Lozano-Juste, J.; Mir, R. Diverse functional interactions between nitric oxide and abscisic acid in plant development and responses to stress. J. Exp. Bot. 2014, 65, 907-921. [CrossRef]

123. Neljubov, D.N. Pflanzen. Beih. Bot. Zentralbl. 1901, 10, 128-139.

124. Hua, J. Isolation of components involved in ethylene signaling. In Ethylene in Plants, 1st ed.; Wen, C.K., Ed.; Springer: Dordrecht, The Netherlands, 2015; pp. 27-44.

125. Abeles, F.B.; Morgan, P.W.; Saltveit, M.E., Jr. Ethylene in Plant Biology, 2nd ed.; Academic Press: San Diego, CA, USA, 2012.

126. Abiri, R.; Shaharuddin, N.A.; Maziah, M.; Yusof, Z.N.B.; Atabaki, N.; Sahebi, M.; Hanafi, M.M. Role of ethylene and the APETALA 2/ethylene response factor superfamily in rice under various abiotic and biotic stress conditions. Environ. Exp. Bot. 2017, 134, 33-44. [CrossRef]

127. Iqbal, N.; Nazar, R.; Syeed, S.; Masood, A.; Khan, N.A. Exogenously-sourced ethylene increases stomatal conductance, photosynthesis, and growth under optimal and deficient nitrogen fertilization in mustard. J. Exp. Bot. 2011, 62, 4955-4963. [CrossRef]

128. García, M.J.; Romera, F.J.; Lucena, C.; Alcántara, E.; Pérez-Vicente, R. Ethylene and the regulation of physiological and morphological responses to nutrient deficiencies. Plant Physiol. 2015, 169, 51-60. [CrossRef] [PubMed]

129. Wang, H.; Liang, X.; Wan, Q.; Wang, X.; Bi, Y. Ethylene and nitric oxide are involved in maintaining ion homeostasis in Arabidopsis callus under salt stress. Planta 2009, 230, 293-307. [CrossRef] [PubMed]

130. Xu, J.; Zhang, S. Ethylene biosynthesis and regulation in plants. In Ethylene in Plants, 1st ed.; Wen, C.K., Ed.; Springer: Dordrecht, The Netherlands, 2015; pp. 1-25.

131. Yang, S.F.; Hoffman, N.E. Ethylene biosynthesis and its regulation in higher plants. Annu. Rev. Plant Physiol. 1984, 35, 155-189. [CrossRef]

132. Chang, C. Q\&A: How do plants respond to ethylene and what is its importance? BMC Plant Biol. 2016, 14, 1-7.

133. Lin, Z.; Zhong, S.; Grierson, D. Recent advances in ethylene research. J. Exp. Bot. 2009, 60, 3311-3336. [CrossRef] [PubMed]

134. Tsuchisaka, A.; Theologis, A. Unique and overlapping expression patterns among the Arabidopsis 1-amino-cyclopropane-1carboxylate synthase gene family members. Plant Physiol. 2004, 136, 2982-3000. [CrossRef] [PubMed] 
135. Lyzenga, W.J.; Booth, J.K.; Stone, S.L. The Arabidopsis RING-type E3 ligase XBAT32 mediates the proteasomal degradation of the ethylene biosynthetic enzyme.; 1-aminocyclopropane-1-carboxylate synthase 7. Plant J. 2012, 71, 23-34. [CrossRef]

136. Ji, Y.; Guo, H. From endoplasmic reticulum (ER) to nucleus: EIN2 bridges the gap in ethylene signaling. Mol. Plant 2013, 6, 11-14. [CrossRef]

137. Dolgikh, V.A.; Pukhovaya, E.M.; Zemlyanskaya, E.V. Shaping ethylene response: The role of EIN3/EIL1 transcription factors Front. Plant Sci. 2019, 10, 1030. [CrossRef]

138. Riyazuddin, R.; Verma, R.; Singh, K.; Nisha, N.; Keisham, M.; Bhati, K.K.; Gupta, R. Ethylene: A master regulator of salinity stress tolerance in plants. Biomolecules 2020, 10, 959. [CrossRef] [PubMed]

139. Khan, M.I.R.; Jahan, B.; AlAjmi, M.F.; Rehman, M.T.; Khan, N.A. Ethephon mitigates nickel stress by modulating antioxidant system.; glyoxalase system and proline metabolism in Indian mustard. Physiol. Mol. Biol. Plants 2020, 26, 1201-1213. [CrossRef]

140. Cui, M.; Lin, Y.; Zu, Y.; Efferth, T.; Li, D.; Tang, Z. Ethylene increases accumulation of compatible solutes and decreases oxidative stress to improve plant tolerance to water stress in Arabidopsis. J. Plant Biol. 2015, 58, 193-201. [CrossRef]

141. Iqbal, N.; Khan, N.A.; Ferrante, A.; Trivellini, A.; Francini, A.; Khan, M.I.R. Ethylene role in plant growth, development and senescence, interaction with other phytohormones. Front. Plant Sci. 2017, 8, 475. [CrossRef]

142. Al Murad, M.; Razi, K.; Benjamin, L.K.; Lee, J.H.; Kim, T.H.; Muneer, S. Ethylene regulates sulfur acquisition by regulating the expression of sulfate transporter genes in oilseed rape. Physiol. Plant. 2020, 171, 533-545. [CrossRef] [PubMed]

143. Shakar, M.; Yaseen, M.; Mahmood, R.; Ahmad, I. Calcium carbide induced ethylene modulate biochemical profile of Cucumis sativus at seed germination stage to alleviate salt stress. Sci. Hortic. 2016, 213, 179-185. [CrossRef]

144. Zhang, X.; Shi, Z.; Tian, Y.; Zhou, Q.; Cai, J.; Dai, T.; Jiang, D. Salt stress increases content and size of glutenin macropolymers in wheat grain. Food Chem. 2016, 197, 516-521. [CrossRef]

145. Liu, C.; Li, J.; Zhu, P.; Yu, J.; Hou, J.; Wang, C.; Zhao, A. Mulberry EIL3 confers salt and drought tolerances and modulates ethylene biosynthetic gene expression. Peer J. 2019, 7, e6391. [CrossRef]

146. Shi, S.; Li, S.; Asim, M.; Mao, J.; Xu, D.; Ullah, Z.; Liu, G.; Wang, Q.; Liu, H. The Arabidopsis calcium-dependent protein kinases CDPKs and their roles in Plant growth regulation and abiotic stress responses. Int. J. Mol. Sci. 2018, 19, 1900. [CrossRef] [PubMed]

147. Peng, J.; Li, Z.; Wen, X.; Li, W.; Shi, H.; Yang, L.; Zhu, H.; Guo, H. Salt-induced stabilization of EIN3/EIL1 confers salinity tolerance by deterring ROS accumulation in Arabidopsis. PLoS Gen. 2014, 10, e1004664. [CrossRef] [PubMed]

148. Xu, L.; Xiang, G.; Sun, Q.; Ni, Y.; Jin, Z.; Gao, S.; Yao, Y. Melatonin enhances salt tolerance by promoting MYB108A-mediated ethylene biosynthesis in grapevines. Hortic. Res. 2019, 6, 1-14. [CrossRef]

149. Husain, T.; Fatima, A.; Suhel, M.; Singh, S.; Sharma, A.; Prasad, S.M.; Singh, V.P. A brief appraisal of ethylene signaling under abiotic stress in plants. Plant Signal. Behav. 2020, 15, 1782051. [CrossRef]

150. Fahad, S.; Hussain, S.; Matloob, A.; Khan, F.A.; Khaliq, A.; Saud, S.; Hassan, S.; Shan, D.; Khan, F.; Ullah, N.; et al. Phytohormones and plant responses to salinity stress: A review. Plant Growth Regul. 2015, 75, 391-404. [CrossRef]

151. Xu, H.; Liu, Q.; Yao, T.; Fu, X. Shedding light on integrative GA signaling. Curr. Opin. Plant Biol. 2014, 21, 89-95. [CrossRef]

152. Yang, R.; Hong, Y.; Ren, Z.; Tang, K.; Zhang, H.; Zhu, J.K.; Zhao, C. A role for PICKLE in the regulation of cold and salt stress tolerance in Arabidopsis. Front. Plant Sci. 2019, 10, 900. [CrossRef]

153. Li, N.; Han, X.; Feng, D.; Yuan, D.; Huang, L.J. Signaling crosstalk between salicylic acid and ethylene/jasmonate in plant defense: Do we understand what they are whispering? Int. J. Mol. Sci. 2019, 20, 671. [CrossRef]

154. Khan, M.I.R.; Asgher, M.; Khan, N.A. Alleviation of salt-induced photosynthesis and growth inhibition by salicylic acid involves glycinebetaine and ethylene in mungbean (Vigna radiata L.). Plant Physiol. Biochem. 2014, 80, 67-74. [CrossRef]

155. Nazar, R.; Umar, S.; Khan, N.A.; Sareer, O. Salicylic acid supplementation improves photosynthesis and growth in mustard through changes in proline accumulation and ethylene formation under drought stress. S. Afr. J. Bot. 2015, 98, 84-94. [CrossRef]

156. Zhu, T.; Deng, X.; Zhou, X.; Zhu, L.; Zou, L.; Li, P.; Zhang, D.; Lin, H. Ethylene and hydrogen peroxide are involved in brassinosteroid-induced salt tolerance in tomato. Sci. Rep. 2016, 6, 35392. [CrossRef]

157. Buet, A.; Galatro, A.; Ramos-Artuso, F.; Simontacchi, M. Nitric oxide and plant mineral nutrition, current knowledge. J. Exp. Bot. 2019, 70, 4461-4476. [CrossRef] [PubMed]

158. Santolini, J.; André, F.; Jeandroz, S.; Wendehenne, D. Nitric oxide synthase in plants: Where do we stand? Nitric Oxide 2017, 63, 30-38. [CrossRef]

159. Chamizo-Ampudia, A.; Sanz-Luque, E.; Llamas, A.; Galvan, A.; Fernandez, E. Nitrate reductase regulates plant nitricoxide homeostasis. Trends Plant Sci. 2017, 22, 163-174. [CrossRef]

160. Dong, F.; Simon, J.; Rienks, M.; Lindermayr, C.; Rennenberg, H. Effects of rhizopheric nitric oxide NO on N uptake in Fagus sylvatica seedlings depend on soil $\mathrm{CO}_{2}$ concentration.; soil $\mathrm{N}$ availability and $\mathrm{N}$ source. Tree Physiol. 2015, 35, 910-920. [CrossRef] [PubMed]

161. Sun, J.; Zheng, N. Molecular mechanism underlying the plant NRT1. 1 dual-affinity nitrate transporter. Front. Physiol. 2015, 18, 6-386.

162. Wang, J.; Yu, S.X.; Zhang, M.; Cui, X.M. Exogenous nitric oxide-mediated GSH-PC synthesis pathway in tomato under copper stress. Russ. J. Plant Physiol. 2015, 62, 349-359. [CrossRef]

163. Masood, A.; Iqbal, N.; Khan, M.I.R.; Khan, N.A. The coordinated role of ethylene and glucose in sulfur-mediated protection of photosynthetic inhibition by cadmium. Plant Signal Behav. 2012, 7, 1420-1422. [CrossRef] [PubMed] 
164. Saithong, T.; Saerue, S.; Kalapanulak, S.; Sojikul, P.; Narangajavana, J.; Bhumiratana, S. Gene co-expression analysis inferring the crosstalk of ethylene and gibberellin in modulating the transcriptional acclimation of cassava root growth in different seasons. PLOS ONE 2015, 10, e0137602.

165. Wawrzyńska, A.; Sirko, A. To control and to be controlled: Understanding the Arabidopsis SLIM1 function in sulfur deficiency through comprehensive investigation of the EIL protein family. Front. Plant Sci. 2014, 5, 575. [PubMed] 